\title{
COMMENTS
}

\section{A CRITIQUE OF THE STRICT LIABILITY STANDARD FOR DETERMINING CHILD SUPPORT IN CASES OF MALE VICTIMS OF SEXUAL ASSAULT AND STATUTORY RAPE}

\author{
ELLEN LONDON ${ }^{\dagger}$
}

INTRODUCTION

\begin{abstract}
S.F. also contends that he did not have consensual intercourse with T.M. and that he was a victim of a sexual assault by T.M. . . We note that S.F. does not contest that he is the biological father of T.M.'s child. A father has both a legal and moral duty to support his minor children. ${ }^{1}$
\end{abstract}

Victims have rights. Here, the victim also has responsibilities.

A 34-year-old woman seduces a 15-year-old boy and becomes pregnant. She gives birth to a daughter and thereafter applies for Aid to Families with Dependent Children. Is the child's father obligated to pay child support even though he is a victim of statutory rape? ${ }^{2}$

So long as a man engages in an intimate sexual act resulting in his depositing of his sperm with a woman who then becomes pregnant, he is liable for child support. ${ }^{3}$

\footnotetext{
${ }^{\dagger}$ B.A. 2001, Cornell University; J.D. Candidate 2005, University of Pennsylvania. I am grateful to Professor Jennifer Rosato and to Michelle Seldin for their insightful comments and conversations on these issues. Indraneel Sur generously contributed editorial assistance and invaluable advice at every step of this process, and Nick Marsilio kindly shared his research. I especially thank the editors at the University of Pennsylvania Law Review for putting so much energy into this piece and for being so supportive of my work. They all worked with incredible care, and I note that all errors are entirely my own. Finally, I thank Ethan Simonowitz, as this Comment is as much his as it is my own.

${ }^{1}$ S.F. v. State ex rel. T.M., 695 So. 2d 1186, 1188 (Ala. Civ. App. 1996).

${ }^{2}$ County of San Luis Obispo v. Nathaniel J., 57 Cal. Rptr. 2d 843, 843 (Ct. App. 1996) (citation omitted).

${ }^{3}$ Laura W. Morgan, It's Ten O'Clock: Do You Know Where Your Sperm Are? Toward a Strict Liability Theory of Parentage, 11 DivorCE LiTIG. 1, 7 (1999), available at http:// www.childsupportguidelines.com/articles/art199903.html.
} 
As illustrated by the above quotes, U.S. courts use strict liability as the standard for determining child support liability in the case of unmarried parents. The man or woman legally required to make payments each month is the one biologically linked to the child, with no weight given to the existence of any social, psychological, emotional, or other ties between them. Courts give no consideration to the circumstances leading up to or involved in that biological connection, and they do not require consent to the sexual relation. That accountable person is almost always the father, and with the common use of DNA testing, it is practically impossible for a man to deny biological paternity. ${ }^{4}$ While there are good arguments for a bright-line rule (e.g., simplification of the process of securing child support for single mothers), the use of strict liability has problematic implications for societal conceptions of gender. This rigid legal standard is justified by traditional notions of aggressive men, weak women, and the nuclear, heterosexual family. The discourse employed by the courts denies male victimization and ensures that women remain subordinate in the

\footnotetext{
${ }^{4}$ Jenny Skoble, No: Biology Shouldn't Always Be Considered as Destiny in Child-Support Cases, InSIGHT ON THE News, May 6, 2002, at http://www.insightmag.com/news/ 249708.html. Jenny Skoble notes that such testing is routine and reliable:

Since the early 1990s, DNA testing for paternity has been in widespread use across the country. These tests are highly accurate and now can be done without even having to draw blood. In the 'buccal-swab' method, saliva is taken from a subject's mouth with a cotton swab. In many states, these tests are performed routinely in the offices of the state's child-support agency.

Id. In one year, the Los Angeles County Child Support Services Department "established paternity for more than 65,000 children, and distributed over $\$ 428$ million dollars for families." L.A. County Child Support Serv. Dep't, Homepage, at http:// childsupport.co.la.ca.us (last visited Apr. 30, 2004). States authorize paternity tests in cases involving dispute on the part of one of the alleged parents, and the parties are required by the court to submit to the testing. Law Offices of Aaron Dishon, PaternityNet.com, California Paternity Actions, at http://www.paternitynet.com/art08. html (last modified Nov. 13, 2003). For example, in Arkansas, the trial court must
} order

the putative father, mother, and child to submit to scientific testing for paternity, which may include deoxyribonucleic acid testing, to determine whether or not the putative father can be excluded as being the biological father of the child and to establish the probability of paternity if the testing does not exclude the putative father.

$\cdots$

If the results of the paternity tests establish a ninety-five-percent or more probability of inclusion that the putative father is the biological father of the child, after corroborating testimony of the mother in regard to access during the probable period of conception, it shall constitute a prima facie case of establishment of paternity, and the burden of proof shall shift to the putative father to rebut such proof.

ARK. Code ANN. §§ 9-10-108(a) (1) \& (6) (A) (Michie 2002). 
traditional hierarchy, and the underlying assumption of such discourse is that men are responsible for their sexuality, or that they have agency, ${ }^{5}$ in a way that women do not. The purported "best interests of the child" objective of this strict liability standard ${ }^{6}$ is a simplistic phrase employed uncritically by courts that do not want to involve themselves in the dynamics of gender and sex in the cases before them. ${ }^{7}$ In this

${ }^{5}$ E.P. Thompson's classic work The Making of the English Working Class is an example of an early study based on the notion of "agency." E.P. THOMPSON, THE MAKING OF THE ENGLISH WORKING CLASS (1963). Thompson argued that class consciousness arose from working class individuals themselves rather than simply from external economic factors. He describes his book as follows:

This book has a clumsy title, but it is one which meets its purpose. Making, because it is a study in an active process, which owes as much to agency as to conditioning. The working class did not rise like the sun at an appointed time. It was present at its own making.

Id. at 9 (second emphasis added).

Laura Engelstein is another scholar who has examined this term, "agency," and her study is a useful point of analysis for this Comment. She looks at prostitutes in Russia at the turn of the century, exploring the complex interaction of legal regulations and gender. The Russian laws may be compared to the strict liability standard for child support for male victims of sexual crimes. She explains that the "laws regulating sexual conduct cast such males ... almost exclusively as culprits and women as victims, granting men the privilege of agency that women were denied." LAURA ENGELSTEIN, The KeYs TO HapPiness: SEX AND THE SEARCH FOR MODERNITY IN Fin-DE-SiÈcle RUSSIA 74 (1992). Engelstein further writes that:

On the one hand, the continuing ... restrictions on women's right to sexual self-determination reflected the lawmakers' desire to protect them from the abuse of power and authority to which they were subject in the domestic and sexual realm. On the other hand, the reluctance to acknowledge their sexual agency kept them in the position of subordination that had established that very vulnerability in the first place. Id. at 75 .

${ }^{6}$ See, e.g., S.F. v. State ex rel T.M., 695 So. 2d 1186, 1189 (Ala. Civ. App. 1996) (describing the interests of the child as being paramount to any other parties' concerns); Hamm v. Office of Child Support Enforcement, 985 S.W.2d 742, 746 (Ark. 1999) (upholding the trial court's consideration of the "children's best interests" in ruling against a male victim of sexual misconduct); Nathaniel J., 57 Cal. Rptr. 2d at 844-45 (holding that the state's interest in protecting children outweighs the defendant's claims of victimization); State v. Daniel G.H. (In re Paternity of Derek S.H.), 2002 WI App 85, I 11 (per curiam), 642 N.W.2d 645 (Wis. Ct. App. 2002) (unpublished table decision) ("The paramount goal of any child support decision is to secure the best interests of the child.").

${ }^{7}$ The work of feminist historian Joan Wallach Scott is helpful in distinguishing between the terms "gender" and "sex." JOAN WALLACH SCOTT, GENDER AND THE POLITICS OF History 32 (1999). She maintains that sexual (biological) difference between men and women is distinct from gender: "Gender is . . . a social category imposed on a sexed body." Id. The categories of gender and sex often overlap in the process of analysis, but as I explore in this Comment, the courts in the cases examined often conflate the two. Specifically, the courts often impose their own gendered notions of masculinity upon male victims, regardless of who may be the male victim. 
Comment, I argue that strict liability is an inappropriate standard to use, illustrated by an analysis of two cases involving male victims of statutory rape and sexual assault. Before examining these cases, I briefly discuss why scholars and policymakers should engage this issue. I also argue that feminists, ${ }^{8}$ in particular, should be challenging this use of strict liability.

Much energy currently is being devoted to reproductive rights, especially as prochoice groups are fighting the Partial-Birth Abortion Ban Act ${ }^{9}$ in the federal courts. ${ }^{10}$ The Left is at a critical juncture, and, in light of the enormous obstacles presented by this Act and its supporters, a challenge to a child support standard, which brings much-needed funding to single mothers and their children, appears inconsequential or even offensive. ${ }^{11}$ This is the challenge taken up by

${ }^{8}$ I will be using the term "feminist" throughout this Comment to mean any person who is invested in contesting and rethinking traditional gender relationships.

9 Partial-Birth Abortion Ban Act of 2003, 18 U.S.C.S. § 1531. The term "partialbirth abortion" is generally objectionable to prochoice advocates. Melissa C. Holsinger, Note, The Partial-Birth Abortion Ban Act of 2003: The Congressional Reaction to Stenberg v. Carhart, 6 N.Y.U. J. LEgIS. \& PUB. POL'Y 603, 603 n.4 (2003). In fact, two later bills, Late Term Abortion Ban Act of 2003, H.R. 679, 108th Cong. (2003); Late Term Abortion Restriction Act of 2003, H.R. 809, 108th Cong. (2003), were introduced in Congress and omitted the use of the partial-birth language entirely. Holsinger, supra at 608 n.46. The two terms, "partial-birth abortion" and "late-term abortion," are interchangeable.

${ }^{10}$ See Jonathan Groner, Challengers to Abortion Law Rally Around the Precedent, LEGAL Times, Nov. 10, 2003, at 3 (discussing the legal strategy of prochoice groups in federal court battles over the partial-birth abortion ban); see also Bush Signs Late-Term Abortion Law, CHI. TRIB., Nov. 6, 2003, at 8 (reporting an injunction by a Nebraska district court judge against the partial-birth abortion law); John M. Glionna, Another Judge Rules Against New Abortion Law, L.A. TIMES, Nov. 7, 2003, at A31 (describing an injunction by a California district court judge); Susan Saulny, Court Blocks New Statute that Limits Abortions, N.Y. TIMES, Nov. 7, 2003, at A18 (describing a similar ruling in the Southern District of New York). In response to the lawsuits following the Partial-Birth Abortion Ban Act, the Justice Department subpoenaed medical records of women who had abortions in several major hospitals, sparking renewed controversy over the privacy rights of these women. See The Hunt for Abortion Records, CHI. TRIB., Feb. 18, 2004, at 14 (asserting that the gathering of abortion records was "an overzealous defense of a flawed law"); Eric Lichtblau, Ashcroft Defends Subpoenas, N.Y. TIMES, Feb. 13, 2004, at A27 (quoting Attorney General John Ashcroft as saying, "we need to look at medical records to find out if indeed there was medical necessity" for the challenged abortions); Medical Privacy Falls Victim to Fierce Abortion Fight, USA TODAY, Feb. 20, 2004, at 8A (characterizing the subpoenas as a "chilling threat[] to medical privacy"). But see Eric Lichtblau, Justice Department Backs Off Its Demand for Abortion Records, N.Y. TIMES, Mar. 10, 2004, at A20 (describing the actions of the Justice Department in dropping some of its demands for medical records on abortions).

${ }^{11}$ It would be wrong to ignore these deeply rooted problems underlying the support for a strict liability standard. See, e.g., Nancy D. Polikoff, The Deliberate Construction of Families Without Fathers: Is It an Option for Lesbian and Heterosexual Mothers?, 36 SANTA CLARA L. REV. 375, 376 (1996) (noting that in constructing her arguments for families 
feminist scholars and activists Wendy Brown and Janet Halley in their collaborative collection entitled Left Legalism/Left Critique. ${ }^{12}$ They argue that critiquing leftist projects is not only necessary, but is also empowering in that it paves the way for innovative thinking and coalitionbuilding, even at a time when important rights are at stake. ${ }^{13}$ Brown and Halley assert that the very process of critique is valuable, in part because it offers a way to analyze our present discourses, structures of power, political choices, and the sources of such choices. ${ }^{14}$ It also "invites us to dissect our most established maxims and shibboleths, not only for scholastic purposes, but also for the deeply political ones of renewing perspective and opening new possibility."1.

Thus, scholars and policymakers must not be paralyzed by the debate over abortion. In fact, the encroachments on, and threats to, reproductive freedom are added reasons to engage in critique, to reexamine the discourses that they employ, and as in the child support cases involving male victims, to question even those laws that may at first glance appear liberal, ${ }^{16}$ and even feminist. ${ }^{17}$ This is a historic moment in which the hegemony of many traditional norms related to gender, sex, and the family is being highly contested, ${ }^{18}$ and leftist

without fathers, she must acknowledge "a larger social context of male indifference to the consequences of sexual intercourse and male irresponsibility for the economic well-being of the children they sire").

${ }^{12}$ LEFT LEGALISM/LEFT CRITIQUE (Wendy Brown \& Janet Halley eds., 2002).

${ }^{13}$ See Wendy Brown \& Janet Halley, Introduction to LeFT LEGALISM/LEFT CRITIQUE supra note 12, at 29 ("[E]ven as critique brings out the tensions, problems, or binds in a particular political formation, it also has the capacity to reconnect us to our aims and hopes....").

${ }^{14}$ See id. at 26-27 ("Critique is ... a practice that allows us to scrutinize the form, content, and possible reworking of our apparent political choices.").

${ }^{15} I d$. at 27.

${ }^{16}$ See, e.g., Joseph I. Lieberman, Child Support in America: Practical Advice FOR Negotiating-AND COLlecting-A FAir SetTlement, at ix (1986) ("Child support in America is a national disgrace. There is no more widespread and profoundly consequential example of lawlessness in our society today than fathers' refusal to care for their children after divorce."). Joseph Lieberman wrote Child Support in America while he was the attorney general of Connecticut, and he observed firsthand many of the issues associated with collecting child support. Id. at ix-x. He concluded that "the failure of delinquent fathers to pay child support is the major reason why more than half the American families that are headed by a woman live below the poverty level." Id. at $\mathrm{x}$.

${ }^{17}$ See id. at 9 (describing how child support enforcement was taken up as a political cause by women's groups).

${ }^{18}$ While reproductive rights are at a critical juncture, the institution of marriage is similarly at a political crossroads. The gay rights movement won a decisive victory in the recent Lawrence v. Texas decision, Lawrence v. Texas, 123 S. Ct. 2472, 2484 (2003) (holding that a Texas statute criminalizing same-sex sexual conduct violated the Due Process Clause of the Fourteenth Amendment), and many people are now wondering 
activists have a unique opportunity to advocate for changes in longheld beliefs and institutions.

Cases of male victims of sexual crimes who are required to pay child support may seem an odd choice for analysis and critique. These cases are not, however, simply aberrations within family law. Rather, these seemingly extreme situations are "border cases" ${ }^{19}$ that illuminate broader legal issues involving gender and sexuality. In these cases-as opposed to those raising issues such as misrepresentations regarding birth control $^{20}$ - the facts present clear, bodily invasion

what will happen next not only for lesbian and gay couples, but for marriage and the traditional family in general. The Goodridge decision and other developments brought the issue of gay marriage to national prominence and increased debate. See Goodridge v. Dep't of Pub. Health, 798 N.E.2d 941, 948 (Mass. 2003) (holding that same-sex marriage could not be denied under the Massachusetts constitution). Compare Opinions of the Justices to the Senate, 802 N.E.2d 565, 572 (Mass. 2004) (concluding that a state civil union bill would not meet state constitutional requirements because it would not give same-sex couples full marriage rights), and Dean E. Murphy, San Francisco Judge Rules Gay Marriages Can Continue, N.Y. Times, Feb. 21, 2004, at A8 (reporting the view of some observers that the marriage license debate "was becoming more rooted in legal, not political, ground [s]"), with Michael Martinez, N.M. Halts Brief Run of Same-Sex Marriages, CHI. TriB., Feb. 21, 2004, at C1 (reporting New Mexico attorney general's issuing of an advisory opinion against same-sex marriages), Elizabeth Mehren, Same-Sex Marriage Divides Mass, L.A. TIMES, Feb. 17, 2004, at A9 (describing sharply polarized legislative debate on the issue of same-sex marriage), James W. Pindell \& Yvonne Abraham, N.H. Bill Targets Same-Sex Marriage: Effects to be Sweeping, Gay Advocates Caution, Boston Globe, Feb. 18, 2004, at B1 (describing proposed legislation in New Hampshire that would refuse to recognize same-sex unions or marriages permitted in other states), and Wedding Zinger: Marriage Amendment Faces Fight, CHI. TRIB., Feb. 19, 2004, at 11 (opining that a constitutional amendment to ban same-sex marriages would be difficult to pass and "[t] hat's what the Founding Fathers intended").

${ }^{19}$ See Rachel Bowlby, Book Review, 9 Tulsa STUD. IN WOMEN's Literature 314, 314 (1990) (reviewing Mary PoOvey, Uneven Developments: THE IdEOlOGICAL WORK OF GENDER IN Mid-Victorian ENGLAND (1988), and describing Poovey's use of "border cases" in her study of sexual and social norms in Victorian England). Rachel Bowlby claims that these border cases "are interesting for the ways in which they challenge or fail to fit prevailing sexual and social norms and thus by their oddness show up the limits and contradictions of those norms." $I d$.

${ }^{20}$ In a series of cases, each father argued that he should not have to pay child support to a mother who lied to him about her use of contraception or her ability to get pregnant. Courts uniformly reject such claims by fathers. See, e.g., Stephen K. v. Roni L., 164 Cal. Rptr. 618, 620 (Ct. App. 1980) (It "is nothing more than asking the court to supervise the promises made between two consenting adults as to the circumstances of their private sexual conduct. To do so would encourage unwarranted governmental intrusion into matters affecting the individual's right to privacy"); Hur v. Virginia Dep't of Soc. Servs. Div. of Child Support Enforcement, 409 S.E.2d 454, 457-58 (Va. Ct. App. 1991) (rejecting the father's argument that the mother was liable to him for infliction of emotional harm because "[t]he evidence sufficiently demonstrated that [the father] voluntarily engaged in sexual relations with [the mother]"); Linda D. v. Fritz C., 687 P.2d 223, 227 (Wash. Ct. App. 1984) ("Nothing in [the applicable child support statute] permits parents in an action brought thereunder to litigate the issue of whether 
and lack of consent on the part of the male victim. Scholars of gender and sexuality will hopefully lay the groundwork for further analysis of the less clear cases.

Some people, namely the so-called fathers' rights groups, do not consider these border cases to be marginal in the least. ${ }^{21}$ These groups claim that men are treated unfairly in the family law context and that many of the current regulations (such as child support determinations) are unreasonable. ${ }^{22}$ The fathers' rights groups are interesting in the context of this Comment, as many of the organizations present an alternative image to the "deadbeat dad"; these groups assert a more nuanced version of masculinity that encompasses themes of equal responsibility and care for children. For example, the American Coalition of Fathers and Children maintains that "through our involvement and dedication, we can have a positive effect on the emotional and psychological well-being of children." ${ }^{23}$ The arguments made by these groups are simplistic and often antifeminist and overly hostile, ${ }^{24}$ but they represent a viewpoint largely ignored by both the

or not they in fact wanted the child."). See generally Morgan, supra note 3 (citing these and several similar cases in state courts).

${ }^{21}$ For example, the National Center for Men's Voluntary Fatherhood Project discusses the "highly discriminatory" nature of current paternity laws. National Center for Men, Voluntary Fatherhood Project, Homepage, at http:/ / www.nas.com/c4m (last visited Apr. 30, 2004). The group's stated goal is "fostering a dialog [sic] about reducing discrimination and out of wedlock births." Id. For other internet sites of a similar theme, see A-Team, Homepage, at http://www.a-team.org (last visited Apr. 30, 2004); American Fathers Coalition, Homepage, at http://users.erols.com/afc (last visited Feb. 27, 2004); Fathers' Rights \& Equality Exchange, Homepage, at http://www.dadsrights.org/index1 .html (last visited Apr. 30, 2004); Fatherhood Coalition, PROTEST: The War on Fatherhood, at http:/ /www.fatherhoodcoalition.org (last visited Apr. 30, 2004).

${ }^{22}$ See, e.g., Alliance for Non-Custodial Parents [sic] Rights, Family Law-Child Support-Father's Rights, at http://www.ancpr.org (last visited Apr. 30, 2004) (discussing the "injustices in family court"). One of the main themes of the fathers' rights groups' Web sites is anger over the lack of joint custody of children. See, e.g., id. ("Fathers are routinely discriminated against in family court."). But see Gloria Woods, "Father's Rights" Groups: Beware Their Real Agenda, NATIONAL NOW TIMES (National Organization for Women, Washington, D.C.), Mar. 1997, http://www.now.org/nnt/03-97/ father.html (representing Michigan NOW and opposing forced joint custody as an unrealistic and inadequate solution for women, children, and divorced families in general).

${ }^{23}$ American Coalition for Fathers and Children, Mission Statement, at http://www. acfc.org/about.htm (last visited Apr. 30, 2004).

${ }^{24}$ Many of the fathers' rights groups advocate for changes that are highly problematic to women and feminists. For example, Dads Against Discrimination pledges to "preserve, protect, and defend the father headed family." Jeff Edwards, Dads Against Discrimination, at http://www.menweb.org/throop/orgs/blurb/dads.html (last visited Apr. 30, 2004) (emphasis omitted). In its Family Court Report, the California National Organization for Women found "an insidious, sexist, and dangerously powerful 
legal system and social critiques and are not entirely at odds with leftist goals. These organizations also emphasize the broader point that these cases involve issues of reproduction and the family that are complex and political, as well as deeply personal, for both men and women.

These cases also highlight the tremendous impact of the regulatory state and judicial decision making on the day-to-day details of a person's life. ${ }^{25}$ When a state involves itself in childrearing (or its financing), it directly asserts its sometimes heavy-handed influence on the family. Specifically, the state implements guidelines for determining the exact amount of child support owed, a calculation requiring the disclosure of an individual's personal financial information. ${ }^{26}$ In addition, a judge has the power to shape public perceptions of a sexual or other personal encounter by the manner in which she conducts a trial or writes an opinion. ${ }^{27}$ In analyzing these cases, it is clear that the judicial presentation of the relationships involved is shaped by

movement of men and women whose political agenda has been infused into judicial procedure and process." SheIla HeIm et al., CAL. NAT'L ORG. FOR WOMEN, FAmily COURT REPORT 2002, at 19, available at http://www.canow.org/fam_report.pdf. While distinguishing the "backlash" groups from profeminist men's groups, the report found that the former engaged in such tactics as diverting funds from programs and services like Temporary Assistance for Needy Families, women's shelters, and other sources of funding for female victims of abuse. Id. at 20-21. The fathers' rights groups' agenda, according to the report, is "to avoid child support, impoverish women, and perpetuate a patriarchal suprastructure by which women and children are subjugated to property status." Id. at 23.

${ }^{25}$ Brown and Halley discuss the often unseen role of legal regulation in life, noting that the "law is capable of intensely intimate effects." Brown \& Halley, supra note 13 , at 14 .

${ }^{26}$ See, e.g., ARIZ. Rev. STAT. ANN. § 25-320 app. § 20 (West Supp. 2003) ("The court shall make findings in the record as to: Gross Income, Adjusted Gross Income, Basic Child Support Obligation, Total Child Support Obligation, each parent's proportionate share of the child support obligation, and the child support order."). Each state utilizes guidelines in determining child support award amounts that are based on directives from Congress, and any deviation from the guidelines must be backed by a written justification. Marsha Garrison, The Goals and Limits of Child Support Policy, in Child Support: The Next Frontier 16, 17 (J. Thomas Oldham \& Marygold S. Melli eds., 2000).

${ }^{27}$ Note, specifically, the power of the trial judge. In Daniel G.H., the appellate judge pointed out that the "determination of appropriate child support is committed to the trial court's sound discretion." State v. Daniel G.H. (In re Paternity of Derek S.H.), 2002 WI App 85U, II 9 (per curiam), 642 N.W.2d 645 (Wis. Ct. App. 2002) (unpublished table decision). In this case, the trial court allowed the issue of nonconsent (the father was sexually assaulted) to go to the jury, yet when the jury found that the sexual intercourse was in fact involuntary, the judge still found that the child's interest in receiving support from both parents was the deciding factor. The trial court thus found no reason to deviate from the "percentage of income" standard for determining how much child support would be required. Id. at *2, *4. 
individuals' gendered assumptions, and it is equally clear that judges may not be aware of their own use of gendered discourse. In determining child support liability, the court essentially dictates the meaning of the initial sexual connection, delineating the legal definition of sexual agency that individuals have vis-à-vis their partners. As Brown and Halley conclude, "law and the state are . . importantly productive of identity and subjectivity." ${ }^{28}$

These questions and problems address just one aspect of an entire system in need of examination. The issues of strict liability and child support in cases of statutory rape and sexual assault are deeply connected to an ever-increasing array of questions arising in the context of new reproductive technologies. ${ }^{29}$ While many of these questions are beyond the scope of this Comment, Part III will provide suggestions, applicable beyond the two cases examined below, for a more critical approach to the issues related to childrearing and the family.

In Part I of this Comment, I present the current legal situation regarding child support and describe how this situation plays out in two different cases. In Part II, I critique this legal standard, using ideas from feminist writers and masculinity studies. Finally, in Part III, I present some suggestions, possibilities, and hopes for the future. In doing so, however, I keep in mind the following assertion by Brown and Halley: The "aim of critique is to reveal subterranean structures or aspects of a particular discourse, not necessarily to reveal the truth

${ }^{28}$ Brown \& Halley, supra note 13, at 7. Brown and Halley point out that one of the dangers of our legalized system is that we forget that legal regulations (rather than just "culture" or "society") also profoundly impact individual perceptions and identities. See id. at 13 "Because law can take the shape of permissions rather than prohibitions, it can invisibly capacitate social and cultural actors to do particular kinds of social and cultural work."). Scott also discusses the role of law and of politics in creating definitions of gender. SCOTT, supra note 7, at 41-50 (encouraging historians to reconsider political and legal questions in terms of gender and power as both constitutive of and resulting from social relationships).

${ }^{29}$ See, e.g., Dion Farquhar, Reproductive Technologies Are Here to Stay, SOJOURNER, Jan. 1995, at 5, 6, available at http://www.hsph.harvard.edu/rt21/procreative/ Farquhar.htm ("The question of whether reproductive technologies benefit or harm their users, providers, and society as a whole has become an important element of contemporary feminist debate."); see also Judith F. Daar, Assisted Reproductive Technologies and the Pregnancy Process: Developing an Equality Model to Protect Reproductive Liberties, 25 AM. J.L. \& MED. 455, 456 (1999) (suggesting that "current disputes over the disposition of frozen embryos" will "grow increasingly fierce and complicated"); Adam P. Plant, With a Little Help from My Friends: The Intersection of the Gestational Carrier Surrogacy Agreement, Legislative Inaction, and Medical Advancement, 54 ALA. L. REV. 639 (2003) (discussing the laws' ability to relate to the emerging practice of gestational carriers). 
of or about that discourse. What critique promises is not objectivity but perspective ....",

\section{The CurRent Situation: A Strict Liability Theory OF SPERm}

Child support has "come of age." ${ }^{31}$ Once the "stepchild" of family law, it is now central in discussions and regulations of the family. June Carbone traces the change in child support policy from its previous emphasis on marriage to its current emphasis on the parent-child relationship. ${ }^{33}$ Child support began in England several hundred years ago both as a penalty for those who violated social custom and as a way to offset public expense. ${ }^{34}$ The advent of state aid to dependent children-and the subsequent federal version in $1935^{35}$ - brought further moral policing as the states were given the discretion to exclude nonmarital children. ${ }^{36}$ This changed in the 1960s when barriers to these children were deemed invalid. ${ }^{37}$ With more children eligible for child support, Congress shifted its focus to finding fathers and enforcing individual support obligations. As part of this effort, in 1975 Congress set up the Office of Child Support Enforcement, ${ }^{38}$ and those individuals seeking funds from Aid to Families with Dependent Children

${ }^{30}$ Brown \& Halley, supra note 13 , at 26 . The use of discourse analysis may be traced to Michel Foucault. His scholarship has become a dominant form of contemporary cultural analysis. 1 Michel FoucAult, THE History OF SEXUALITY (Robert Hurley trans., Random House 1978) (1976). Joan Scott also emphasizes the centrality of language in looking at gender. She writes that "words, like the ideas and things they are meant to signify, have a history." SCOTT, supra note 7, at 28.

${ }^{31}$ June Carbone, Child Support Comes of Age: An Introduction to the Law of Child Support, in CHILD SUPPORT: THE NEXT FRONTIER, supra note 26.

${ }^{32} I d$.

${ }^{33}$ Id. at 4.

34 Id. at 4-5.

${ }^{35}$ See Pub. L. No. 74-271, $§ \S ~ 401-406,49$ Stat. 620, 627-629 (1935) (repealed 1996) (setting aside reimbursement funds to assist needy, dependent children). The AFDC program (originally entitled Aid to Dependent Children) was included in Title IV of the Social Security Act of 1935. Id. The program established a system of reimbursement of state funds voluntarily spent on providing support for children.

${ }^{36}$ See Carbone, supra note 31, at 8 ("Congress envisioned the program as a temporary federal assumption of state efforts to provide for children whose fathers had died, and it permitted each state to impose "such other eligibility requirements-as to means, moral character, etc.-it sees fit." (quoting H.R. REP. No. 615, at 24 (1935); S. REP. NO. 628, at 36 (1935)).

${ }^{37}$ See id. ("By the $1960 \mathrm{~s}$... the federal agency charged with administration of the program disapproved of barriers to aid based on illegitimacy alone ....").

38 See Child Support Enforcement Act, 42 U.S.C. $\$ \$ 651-669$ (1975) (creating the Child Support Enforcement program under Title IV-D of the Social Security Act). 
(AFDC) $)^{39}$ had to cooperate in locating absent parents and obtaining support payments as a prerequisite for receiving funds. ${ }^{40}$

In the late 1980s and early 1990s, there was growing concern regarding the lack of child support being paid and the accompanying effects that such delinquency had on children. ${ }^{41}$ In response to this concern, Congress passed the Family Support Act of $1988^{42}$ (commonly called the Child Support Act), requiring states to establish, improve, and more actively enforce their child support systems. ${ }^{43}$ The modern system, brought about by the Child Support Act, is different from previous approaches in that the duty to provide child support is not only treated more seriously, but-and vital to note-is a requirement separate from other family obligations, such as marriage. ${ }^{44}$ This change came about in response to rising divorce rates and rising numbers of single-parent families; ${ }^{45}$ policymakers realized that parenthood is a more stable hook on which to hang support obligations than is the marital relationship. ${ }^{46}$

Not only do state child support guidelines now focus on the parent-child relationship rather than on marital status, but the guidelines also focus exclusively on the parent's biological relationship to the child. ${ }^{47}$ Laura Wish Morgan writes about how this biological

${ }^{39}$ The Personal Responsibility and Work Opportunity Reconciliation Act, Pub. L. No. 104-193, 110 Stat. 2105 (1969) (codified as 42 U.S.C. $\$ \$ 601-619$ (2000)), "ended the federal entitlement to Aid to Families with Dependent Children (AFDC) and replaced it with block grants to states, thereby shifting the major responsibility for helping poor families to state and local governments." This new program, Temporary Assistance to Needy Families (TANF), supplanted the AFDC program and made funding contingent on the applicant's efforts to find or prepare for employment. Paul K. Legler, The Impact of Welfare Reform on the Child Support Enforcement System, in CHILD SUPPORT: THE NEXT FRONTIER, supra note 26, at 46.

${ }^{40}$ Legler, supra note 39.

${ }^{41}$ See id. at 9 (describing the "declining well-being of American children").

${ }^{42}$ Pub. L. No. 100-485, 102 Stat. 2343 (codified at 42 U.S.C. $§ 667$ (b) (2) (2000)).

${ }^{43}$ See Carbone, supra note 31, at 9-10 (describing the states' obligations established by the Family Support Act of 1988).

${ }^{44} I d$. at 10

${ }^{45} I d$. at $10-11$.

${ }^{46} \mathrm{Id}$.

${ }^{47}$ Courts that have the power to determine child support obligations find that, if certain physical requirements are satisfied, the judicial role is simply to determine the amount to be paid; the context of the conception need not be examined. For example, in Illinois:

If the child was born out of wedlock and the case is subject to the voluntary acknowledgement of paternity or the administrative determination of paternity under rules established under Section 10-17.7, the Child and Spouse Support Unit of the Illinois Department shall determine the child support 
connection is played out in various scenarios, and she finds thatregardless of the context-the father is uniformly held responsible by courts for his child support obligations. ${ }^{48}$ Morgan begins her discussion examining cases in which the mother made misrepresentations regarding her use of birth control or her ability to get pregnant, explaining that such misrepresentations have never been a viable defense to the father of the child. ${ }^{49}$ Morgan also examines cases in which the man did not engage in sexual intercourse, namely, cases in which a man provided sperm to a woman for artificial insemination with the express agreement that he would not be liable for supporting the child. ${ }^{50}$ Here as well, the courts held that-if the parties did not comply with local statutes governing artificial insemination-"a mother simply cannot waive child support on behalf of the child and the father cannot waive his parental rights" on grounds of public policy. ${ }^{51}$ In an even more extreme example, Morgan describes a case in which a woman offered to perform oral sex on a man (who wore a condom) and then subsequently removed the condom and used it to inseminate herself with the man's sperm. ${ }^{52}$ Once again, the court found that because this man was the father of the woman's child, he was liable for child support payments. ${ }^{53}$ Morgan also analyzes cases of pregnancy resulting from incidents of sexual assault and statutory rape. ${ }^{54}$ In her discussion, Morgan examines instances of male victims of statutory rape who are "legally incapable of 'intending' to have sexual intercourse" due to their underage status, ${ }^{55}$ but who are nonetheless

obligation under subsection (b) of Section 10-7 upon establishing the child's paternity.

305 ILl. COMP. STAT. 5/10-6 (2001). As described in Morgan's article, the courts have enforced this duty as though the paternity determination leads to strict liability for child support. See generally Morgan, supra note 3, at 4-9 (discussing various cases of strict liability child support despite possible tort liability, statutory rape, artificial insemination on the part of the mother, and lack of consent or intent by the father).

48 See Morgan, supra note 3, at 4-9 (concluding that, "[i]f a man intends to have sexual intercourse with a woman and a baby results, the man is liable for child support").

${ }^{49} I d$. In these cases, fathers have unsuccessfully put forth legal defenses using the Fourteenth Amendment right to privacy, the Fourteenth Amendment guarantee of equal protection, and tort liability for fraud and misrepresentation. Id.

${ }^{50} I d$. at $5-6$.

${ }^{51} I d$. at 6.

${ }^{52} I d$. at 7 ("[B] ecause the father intentionally engaged in a sexual act resulting in his deposit of sperm with the mother, he was liable for child support." (citing State v. Frisard, 694 So. 2d 1032 (La. Ct. App. 1997))).

${ }^{53}$ Frisard, 694 So. 2d at 1034.

${ }_{54}^{54}$ Morgan, supra note 3, at 5.

${ }^{55} I d$. 
held strictly liable under child support regulations. ${ }^{56}$ Morgan also examines a case in which a man who was unconscious during sexual intercourse was nonetheless found to be liable for child support. ${ }^{57} \mathrm{Al}-$ though both of these cases will be analyzed in greater detail below, it is already clear why Morgan has coined the legal policy in such cases a "strict liability theory of sperm.

\section{A. The Cases of Nathaniel J. and S.F.}

Although, as Morgan demonstrates, this strict liability theory is played out in many contexts, two exemplary cases illustrate this theory in action-County of San Luis Obispo v. Nathaniel J. ${ }^{59}$ and S.F. v. State ex rel. T.M. ${ }^{60}$ Both cases illustrate the imposition of the strict liability theory in particularly disturbing ways, ${ }^{61}$ and both involve sexual crimes on the part of the mother. The first case, Nathaniel J., was initiated by the county as a paternity action to recover child support for a child born to Nathaniel J. and a woman named Ricci Jones. ${ }^{62}$ Jones was 34 when she had sexual intercourse with Nathaniel J., then aged $15{ }^{63}$ Although Jones was convicted of unlawful sexual intercourse with a minor, ${ }^{64}$ the district attorney sought child support and welfare reimbursement from Nathaniel $\mathrm{J}^{65}$ As a defense against the child support request, Nathaniel J. invoked his status as a statutory rape victim, claiming that both public policy against sexual exploitation and his rape).

${ }^{56}$ See id. (discussing child support obligations in the context of male statutory

${ }^{57}$ See id. at 7-8. (discussing S.F. v. State ex rel T.M., 695 So. 2d 1186 (Ala. Civ. App. 1996), a case where the father claimed that he should not be responsible for child support because the mother had sexual intercourse with him while he was intoxicated, and he therefore could not have consented to intercourse).

${ }^{58}$ See Morgan, supra note 3 , at 8.

${ }^{59} 57$ Cal. Rptr. 2d 843 (Ct. App. 1996).

${ }^{60} 695$ So. 2d 1186 (Ala. Civ. App. 1996).

${ }^{61}$ There are many arguments regarding strict liability and efficiency. In this Comment, I am operating on the premise that the strict liability that results from the courts' consistent refusal to take into account male victimization as a defense against child support liability is an overly rigid-and thus unfair-system that cannot be justified on efficiency grounds. As will be discussed below, it is disturbing because it relies on stereotypes and contributes to a traditional way of thinking about both men and women. In general, it is also troubling that such laws go unchallenged and that the desire to avoid confronting complicated and emotional ideas carries so much weight.

${ }^{62}$ Nathaniel J., 57 Cal. Rptr. 2d at 844.

${ }^{63} \mathrm{Id}$.

${ }^{64}$ Id. The mother was convicted under CAL. Penal Code $§ 261.5(\mathrm{~d})$ (West 1999) (laying out the elements of a statutory rape offense).

${ }^{65} 57$ Cal. Rptr. 2d at 844. 
right as a victim to restitution should relieve him of liability. ${ }^{66}$ The court rejected Nathaniel J.'s argument, stating that the interest in providing equal support to the child from both of her parents outweighed his various claims. ${ }^{67}$ The opinion noted that Nathaniel J. was not an innocent victim because he and Jones decided together to begin engaging in sexual intercourse, and they had intercourse "approximately five times over a two week period." ${ }^{18}$ The court distinguished those crime victims who suffer injury through no fault of their own from those who voluntarily engage in the offensive behavior: "One who is injured as a result of criminal conduct in which he willingly participated is not a typical crime victim. ${ }^{, 9}$ Nathaniel J. apparently fell into this latter category and was thus given an order to pay child support. ${ }^{70}$

S.F. v. State ex rel. T.M. involved a man who was not conscious during a sexual encounter that led to pregnancy and who, therefore, did not consent to the encounter. ${ }^{71}$ In 1992, S.F. was at a party at T.M.'s house, after drinking at a club for several hours beforehand. He passed out and was put to bed by T.M. and his brother, fully clothed. When S.F. woke up the next morning, he was only wearing his shirt (unbuttoned). ${ }^{72}$ T.M. told a friend that she had sex with S.F. while he was passed out and that he had "'saved her a trip to the sperm bank.", "73 A medical doctor testified at trial that a man who is unconscious is physically capable of both erection and ejaculation because these are not conscious, voluntary activities. ${ }^{74}$ There was a $99.47 \%$ probability that S.F. was the father of T.M.'s child. ${ }^{75}$ Although S.F. argued that he should not be held liable for child support due to T.M.'s sexual assault on him, ${ }^{76}$ the lower court ordered S.F. to pay $\$ 120$ per month in child support and $\$ 7,152.40$ as child support arrearage, to

${ }^{66} I d$.

${ }^{67}$ Id. at 845 .

${ }^{68} I d$. at 844 .

${ }^{69}$ Id. (citation omitted).

${ }^{70}$ A similar case is that of State ex. rel. Hermesmann v. Seyer, 847 P.2d 1273 (Kan. 1993). The trial judge in Hermesmann stated: "It's my view . . . that a minor may be held legally liable to provide reimbursement to the State . . . and that the issues of consent and the criminal case and so forth are not really relevant in a paternity proceeding, which we're talking about, civil liability to support a child." Id. at 1275 (quoting the district judge).

${ }^{71} 695$ So. 2d 1186, 1187 (Ala. Civ. App. 1996).

${ }^{72}$ Id.

${ }^{73} I d$. at 1188 (quoting T.M.).

${ }^{74} \mathrm{Id}$.

75 Id. at 1186.

${ }^{76}$ Id. at 1188. 
include the child on his medical insurance, to pay one-half of any medical expenses not covered by insurance, and to pay $\$ 300$ for the cost of the blood tests. ${ }^{77}$ The appellate court, in affirming the lower court's decision, looked at the Alabama Uniform Parentage $\mathrm{Act}^{78}$ and ultimately held that the interests of the child are paramount to any other party's concerns. ${ }^{79}$ The court concluded that "any wrongful conduct on the part of the mother should not alter the father's duty to provide support for the child. We note that the father could have filed criminal charges against the mother." ${ }^{80}$ Judge Crawley, in his dissent, argued that this was an unjust application of the rules, noting that S.F. "never wanted to have any children, and had always taken precautions not to have children." ${ }^{81}$ Crawley would not have denied S.F. all liability; rather, he would have limited it solely to the amount that T.M.'s income could not cover the child's necessary expenses. ${ }^{82}$ In discussing T.M. (a "licentious opportunist"), he noted that the "mother's ingenuity strongly indicates her ability to earn an adequate living for herself and her child." ${ }^{83}$

${ }^{77}$ Id. at $1186-87$.

78 ALA. CODE $§ 26-17-1$ to -22 (1992 \& Supp. 2002).

${ }^{79} 695$ So. $2 \mathrm{~d}$ at 1189 . The S.F. court argued that, "[u]nder the [Uniform Parentage Act], the interests of the illegitimate child are deemed to be paramount to those of the other parties to the proceeding. The interests of the other parties are not completely discounted, but merely subordinated to those of the child." Id. at 1189 (quoting Carlotta P. Wells, Comment, Statutes of Limitations in Paternity Proceedings: Barring an "Illegitimate's" Right to Support, 32 AM. U. L. REv. 567, 612 (1983)). Several other states have passed legislation with similar priorities, including the Maryland code that says

The purpose of this subtitle is (1) to promote the general welfare and best interests of children born out of wedlock by securing for them, as nearly as practicable, the same rights to support, care, and education as children born in wedlock; (2) to impose on the mothers and fathers of children born out of wedlock the basic obligations and responsibilities of parenthood; and (3) to simplify the procedures for determining paternity, custody, guardianship, and responsibility for the support of children born out of wedlock.

Md. Code Ann., Fam. LaW § 5-1002(b) (1999); see also Me. Rev. Stat. AnN. tit. 19-A, § 1653(3) (West Supp. 2003) ("The court, in making an award of parental rights and responsibilities with respect to a child, shall apply the standard of the best interest of the child.").

${ }^{80} 695$ So. 2d at 1189 (citation omitted).

${ }^{81} I d$. at 1191 (Crawley, J., dissenting in part).

${ }^{82} \mathrm{Id}$. ("The child's best interest is paramount. We cannot, without consideration of the mother's ability to support the child, deny her all relief requested.").

${ }^{83} I d$. A very similar (and more recent) case is State v. Daniel G.H. (In re Paternity of Derek S.H.), 2002 WI App 85 (per curiam), 642 N.W.2d 645 (Wis. Ct. App. 2002) (unpublished table decision). Daniel denied paternity against the claims of Jennifer, the mother, (and the state of Wisconsin) on the grounds that he did not consent to sex with Jennifer. Id. I 2. At trial, the jury found that the sex was indeed involuntary (although the jury did not find that he had been given a date rape drug, as he claimed). 


\section{CRitiquing the StRict Liability TheOry OF SpERM}

In many of the cases that Morgan identified, the fathers argued that there was inherent unfairness due to the fact that only the mother could decide whether to bear the child. ${ }^{84}$ To this argument Morgan responds that "what the men have failed to understand is that in all of these cases, the women assumed not only all the 'reproduction rights,' they assumed the reproduction risks of the failure of birth control." ${ }^{, 85}$ Due to biological differences, a man's reproductive choice happens "in the bedroom and not at the abortion clinic or the courtroom." Morgan's final piece of advice to those men who do not want to pay child support for a child they did not plan for or desire is to "[s]hut up and put on a condom." ${ }^{, 87}$ Her comment reflects the underlying attitude of the strict liability standard, namely the law's limited ability to take gender and sexual agency into account in a nuanced and effective way. Both the Nathaniel J. and S.F. courts were unable and/or unwilling to acknowledge that the victims involved were particularly affected due to the fact that they were male. The traditional conceptions of power, dominance, and victimization employed by these courts precluded the judges from providing the defendants with a fair or adequate solution. Little doubt exists that the judges in these cases would have written different opinions if the victims were female-illuminating how men are viewed as the responsible party in a sexual encounter and women have no corresponding agency. ${ }^{88}$ Neither decision discusses the various gender dynamics involved, let alone a concern for gender inequity. Nonetheless, gender

$I d$. I 5. Daniel was nonetheless ordered to make child support payments. Id. I 6. The reviewing court found that the trial court did not abuse its discretion in giving more weight to the child's interest in having support from two parents than to Daniel's lack of consent. Id. II 12.

${ }^{84}$ Supra notes $48-57$ and accompanying text.

${ }^{85}$ Morgan, supra note 3 , at 8.

${ }^{86} I d$.

${ }^{87} I d$. at 9 .

${ }^{88}$ In fact, many states have statutes that terminate or limit paternal rights when a child is conceived as a result of female sexual victimization. See, e.g., Del. Code AnN. tit. 13, § 728(d) (1999) (denying the biological father visitation privileges "[i]f a child is conceived and subsequently born as the result of an act of rape of any degree or unlawful sexual intercourse, in either the first or second degree with the mother"); see also Shepherd v. Clemens, 752 A.2d 533, 540 n.22 (Del. 2000) (listing similar statutes in fifteen other states). While biological differences prevent an exact analogy, it is still clear that male perpetrators both are actively punished and are kept from their children, whereas in the cases presented in this Comment of female perpetrators, the offenders do not appear to suffer adverse consequences from their actions. 
stereotypes $^{89}$ lurk in the background of both opinions: the courts not only upheld notions of traditional masculinity even when directly faced with male victims, but also deprived the mothers of any real power by portraying them as devious, manipulative, or, simply put, pathetic. ${ }^{90}$

Morgan's advice to wear a condom clearly would not have helped S.F. or any man in his situation. ${ }^{91}$ As a result of the prevailing strict liability standard, judges in this case and others do not have to deal with the idea of a male victim of sexual assault by a woman because they are free to focus instead on the paramount interest of the child. This does not change the fact, however, that a male victim is present in S.F., an issue separate and distinct from the interests of his child. As for S.F.'s claims of sexual assault, the opinion stated simply that S.F. could have filed criminal charges against the mother. ${ }^{92}$ By severing the live child from the act of conception, the court can require child support from the male victim without ever addressing whether the man was deceived or even abused. This reasoning shifts the analysis temporally from conception to the moment of, and the time after, childbirth. Implicit in the court's opinion is the idea that its proceedings are simply generating monetary support for a child rather than inflicting any emotional damage on either party, and the judicially imposed payment of such money thus should not be viewed as punishment for the male victim.

Notions of male power and the preservation of the gender/sex status quo are especially visible in the S.F. dissent. Judge Crawley found T.M. distasteful, and in light of her brazenness, was careful to maintain the masculinity of S.F., despite S.F.'s status as "victim." He mentioned that S.F. was " 37 years old, never wanted to have any children, and had always taken precautions not to have children.."93 Judge Crawley portrayed S.F. as a man who was, before T.M. appeared, in control of his life. He described T.M.'s conduct as "reprehensible" (and mentioned that her action that night was a misdemeanor), which should have been sufficient reason for the trial court to deviate from

\footnotetext{
${ }^{89}$ See generally SCOTT, supra note 7, at 31-50 (explaining the necessity of discourse analysis, even when gender stereotypes are not overtly expressed, and the importance of reading gender into language).

${ }^{90}$ Supra Part I.A.

${ }^{91}$ Even Morgan is bothered by the outcome in this case: she writes that the "lesson one must take from S.F. v. T.M. . . is somewhat troubling." Morgan, supra note 3, at 10 .

${ }_{92}^{92}$ S.F. v. State ex rel T.M., 695 So. 2d 1186, 1189 (Ala. Civ. App. 1996).

${ }^{93}$ Id. at 1191 (Crawley, J., dissenting in part).
} 
the child support guidelines. ${ }^{94}$ He opined (snidely) that the mother's "ingenuity" indicates that she should be perfectly capable of procuring money for herself and her child and that " $\mathrm{t}]$ hose who acknowledge President George Washington as the 'father of our country' can breathe a sigh of relief that this licentious opportunist did not fall into Rip Van Winkle's forest bed." ${ }^{95}$ In an effort to sexualize T.M., he mentioned in a footnote that there was evidence that she had attended a party dressed as a condom. ${ }^{96}$ This portrayal implied that she was manipulative in her use of sex. In so doing, the judge reinforced two overlapping gender stereotypes: that of the strong, independent man and that of the devious woman who manipulates power structures through her (overdeveloped) sexuality. ${ }^{97}$

This portrayal of gender relations takes on a slightly different form in cases of male victims of statutory rape, but the gender stereotypes underlying these cases are similarly destructive to both men and women. Ruth Jones explains that statutory rape laws were draftedand are enforced-in light of the female experience. ${ }^{98}$ These laws, thus, do not adequately take into account the unique problems faced by male victims. ${ }^{99}$ Specifically, they do not acknowledge that "male

${ }^{94}$ Id.

${ }^{95}$ Id.

${ }^{96} I d$. at 1191 n.1.

97 See FOUCAULT, supra note 30, at 104 (describing the three-part process in which the female body was "analyzed . . . as being thoroughly saturated with sexuality"; integrated into medical science; and then placed into the family sphere, highlighting the "[m] other, with her negative image of 'nervous woman'" as the most obvious example of hysterization of women).

${ }^{98}$ Ruth Jones, Inequality from Gender-Neutral Laws: Why Must Male Victims of Statutory Rape Pay Child Support for Children Resulting from Their Victimization?, 36 GA. L. REV. 411, 419 (2002). While analyzing the way that the law ignores male victims, it is also useful to ask the following question: If statutory rape law is based on and enforced only in the case of women, what does this then imply about women? The implication is that women-by serving in the role of the victim-are viewed as passive, weak, and in need of protection. The feminist debate over the use of the "reasonable woman standard" also raises this question. While proponents of such a gendered standard argue that "sexualized conduct differentially harms women," some feminists argue-amongst other things - that "an explicitly gendered standard could end up backfiring and reinscribing Victorian notions of morality into Title VII law." MARTHA CHAMALLAS, INTRODUCTION TO FEMINIST LEGAL THEORY 241-45 (1999); see also ENGELSTEIN, supra note 5, at 75 (explaining that the regulations of Russian prostitutes, supposedly a form of protection, actually maintained the subordinate and dependent position of these women in civil society). But cf. Michael M. v. Superior Court, 450 U.S. 464, 473 (1981) (accepting California's position that the legislature designed a non-gender-neutral statutory rape statute to deter female pregnancy and declining to view this statute as "impermissibly underinclusive").

${ }^{99}$ Jones notes that as compared to female victimization, male victimization "has not been adequately studied." Jones, supra note 98 , at 439 . 
victims should also be protected from the long-term, negative consequences resulting from the financial obligations of fatherhood."100 Although the Nathaniel J. court did not appear to view child support payments as imposing any sort of long-lived, nonfinancial harm on Nathaniel J., ${ }^{101}$ Jones explicitly links child support payments to notions of punishment and harm to male victims. ${ }^{102}$ Although scarce, existing data on this subject indicates that men are negatively impacted by being victims of statutory rape ${ }^{103}$ and that becoming a father at a young age affects all aspects of a young man's life, from emotional development to educational and career opportunities. ${ }^{104}$ In this way, then, "[c] ourts have failed to recognize that the financial obligation for a child is one of the consequences of male victimization., ${ }^{105}$

Jones analyzes the failings of the strict liability standard in the context of equality, primarily arguing that "while young men and young women are dissimilar in their ability to become pregnant, they are similar in their need for protection by statutory rape laws." ${ }^{, 166}$ For Jones, the states' highly gendered-though facially gender neutrallaws inadequately protect young men from the harm of male victimization. While agreeing with Jones's equality analysis, I additionally argue that the law's invocation of traditional gender roles is destructive to both men and women by further locking them into stereotypical roles and interactions. Courts distort cases by reconfiguring male victims as dominant and female perpetrators as either passive or devious (due to their lack of power). Viewing the male victims as dominant

100 Id. at 412.

101 County of San Luis Obispo v. Nathaniel J., 57 Cal. Rptr. 2d 843, 845-46 (Ct. App. 1996) (agreeing with other cases in which the "economic consequences" to the father do not override the interest of the child in receiving support).

${ }^{102}$ Jones, supra note 98, at 412-13 (noting that "[b]y imposing financial responsibility to repay state support for an unplanned child," the law penalizes male statutory rape victims and fails to protect them from the "potentially substantial harm" caused by these financial "limitations on their life opportunities").

103 See Roger J.R. LevesQue, Adolescents, SEX, AND THE LAw: PrePARING AdoLESCENTS FOR RESPONSIBLE CITIZENSHIP 76 (2000) ("[F] or boys, a largely excluded group from discussions of the negative impact of early sexual activity, research indicates that males pay an emotional price for beginning a sexual relationship early.”).

104 Id. at 439; see also id. at 298 (noting that negative outcomes of teenage childbearing "include poorer psychological functioning, lower rates of school completion, lower levels of marital stability, additional nonmarital births, less stable employment, greater welfare use, higher rates of poverty, and slightly greater rates of health problems," and that "[t]he growing interest in understanding the impact on fathers reveals that they too become similarly disadvantaged by childrearing and that many of their disadvantages have roots that led to early parenting").

${ }_{106}^{105}$ Jones, supra note 98 , at 439.

106 Id. at 414. 
implies that men are capable of governing themselves, both sexually and generally, in a way that women are not. The court in Nathaniel J. stated that Nathaniel J. was not an "innocent victim" and found the fact that Nathaniel J. himself described the sexual intercourse as "a mutually agreeable act" to be relevant to its decision. ${ }^{107}$ This is an egregious departure from the well-reasoned policy of statutory rape laws, which is the protection of vulnerable young people. ${ }^{108}$

The court ignored the rationale of statutory rape law-that a minor is not mature enough to make decisions regarding sexual intercourse-by implying that Nathaniel J. (as a male) was an active agent in the process and that his female partner could not have been powerful enough to have unduly influenced or controlled him. ${ }^{109}$ As discussed in the next two Sections, these stereotypes undermine the ideals of feminism, work against true gender equality, alienate various political groups, and add to society's collective silence regarding male sexual victimization.

\section{A. A Critique of the Strict Liability Theory}

Both the S.F. and Nathaniel J. courts failed to account for the gender implications of the strict liability standard. Not only did they fail to see that the individuals involved were affected differently because they were male, but they also used language that served to maintain gender stereotypes about both men and women. For both of these reasons-inequality and the furtherance of harmful stereotypesfeminist thinkers should be concerned about this legal policy. Some of the central ideals of feminism regarding reproductive rights are threatened in these cases and analyzing them in light of feminist ideals will only enhance flexible and creative advocacy. ${ }^{110}$

${ }^{107}$ County of San Luis Obispo v. Nathaniel J., 57 Cal. Rptr. 2d 843, 844 (Ct. App. 1996).

${ }^{108}$ See People v. Paz, 95 Cal. Rptr. 2d 166, 168 (Ct. App. 2000) (discussing statutory rape legislation and noting that the language regarding a ten-year age difference "reflects a recognition that a 'sexually naive' child of 14 or 15 could fall victim to a more experienced adult"). In $P a z$, the court rejected a defense to statutory rape charges based on reasonable mistake of age. $I d$. at 171 . Interestingly, the Paz court mentioned a 1964 case that supported the "sound policy that it is in the public interest to protect the sexually naïe female from exploitation." Id. (quoting People v. Hernandez, 39 Cal. Rptr. 361, 365 (1964)) (emphasis added).

${ }^{109} 57$ Cal. Rptr. $2 \mathrm{~d}$ at 844.

${ }^{110}$ See supra notes 11-16 and accompanying text (describing the power of critique to resuscitate Left movements). 


\section{Male Bodily Integrity}

Bodies in general are now understood to be a central aspect of identity, ${ }^{111}$ and while the female body has long been studied and analyzed, many scholars have only recently begun to consider the male body as both socially constructed and formative for selfhood. ${ }^{112}$ Much of this scholarship builds on the ideas of Michel Foucault, who posited that bodies are historically a site of expression and examination on the part of liberal society. ${ }^{13}$ It is clear that the strict liability standard applied in these cases does not take the male body into account on either a basic level (as physically vulnerable and in need of protection) or as an expression of gender or other form of self-identity. Before looking at S.F. and Nathaniel J. in relation to these ideas, it will be helpful to examine one scholar's theory on the meaning of bodily integrity. Drucilla Cornell offers a powerful feminist argument that abortion should be treated not as a privacy right, but rather as a right to "bodily integrity." oped by Jacques Lacan to demonstrate that bodily wholeness is essential to maintaining a basic sense of self in the world. ${ }^{115}$ She explains that we form our self-identity by facing our own reflection in a mirror and imagining that this projection is our true self. To maintain this self-identity, we must be able to imagine that this image of ourself will continue unbroken into the future. ${ }^{116}$ Turning to the question of abortion, Cornell argues that banning the procedure is deeply destructive of bodily integrity because it separates the woman from her womb, turning the womb over to the power of the state. ${ }^{117}$ The woman becomes unable to imagine herself as a whole individual in the future

111 See, e.g., Chris Shilling, The Body ANd Social Theory 1 (1993) (discussing the increased sociological interest in the body and pointing out that in "conditions of high modernity, there is a tendency for the body to become increasingly central to the modern person's sense of self-identity").

112 See generally Susan Bordo, The Male Body: A New LoOK at Men in Public AND IN PRIVATE (1999) (discussing the male body, historically and presently, and how culture has played a role in defining it).

${ }_{113}$ FOUCAULT, supra note 30, at 17-35.

${ }^{114}$ Drucilla Cornell, Dismembered Selves and Wandering Wombs, in LEFT LEGALISM/LEFT CRITIQUE, supra note 12, at 338. In a broader context, the Supreme Court has recognized a limited substantive due process right to bodily integrity: The "Constitution places limits on a State's right to interfere with a person's most basic decisions about .. . bodily integrity." Planned Parenthood v. Casey, 505 U.S. 833, 849 (1992).

${ }^{115}$ Cornell, supra note 114, at 342 (describing Jacques Lacan's writings based on a Freudian notion of the "bodily ego").

${ }^{116}$ See id. (arguing that the Lacanian framework "allows us to understand just how fragile the achievement of individuation is").

${ }^{117}$ Id. at 347 . 
since she cannot rely on the right to an abortion to prevent this severing of her body. ${ }^{118}$

Richard Posner addresses the topic of abortion in Sex and Reason, ${ }^{119}$ attempting to balance his concern for female bodily integrity with the life of a fetus. He asks what a woman loses if "the fetus is extracted and allowed to live, rather than killed." ${ }^{, 20}$ According to Cornell's analysis, a woman loses her sense of self because, without the abortion option, she is forced both into giving birth and into motherhood. ${ }^{121}$ Cornell posits the right to an abortion as the right to prevent a child from being born. ${ }^{122}$

It is interesting to then compare S.F., or even Nathaniel J. (if we understand him as lacking the maturity to make this choice), to a woman in a parallel position, since both are forced into fatherhood involuntarily and/or unwillingly. If the choice to have an abortion is in part a choice regarding parenthood, then there should also be some analysis in the context of male choice regarding reproduction when they could not simply put on a condom and exercise their choice in the bedroom. We do not need to devalue the uniqueness of pregnancy in order to think more critically about male bodies. Rather, we can apply the ideas developed in the context of female reproductive rights and use them to problematize the oversimplified solution of the strict liability approach to child support. One of the major problems of the strict liability standard is that it leaves no room to account for the bodily integrity of a male victim, and without a more nuanced standard, the courts have no need (or desire) to address the issue. It is then left to feminists and others interested in deconstructing gender definitions in the law to make some sense of this balance and to delineate the ways that the ideal of bodily integrity can be upheld for both men and women.

The first issue S.F. raises is the problem of bodily assault. Cornell writes that, "in a case of physical assault, one's sense of projected unity is completely shattered. Physical violence imposes a horrifying dualism of self. In a violent assault we are reduced to 'some body': as

\footnotetext{
${ }^{118} I d$. The next step in the analysis is to say that the severing of the female body effectively places it under male control. Id. at 347-48.

119 See generally RICHARD A. POSNER, SEX AND REASON 272-90 (1992) (discussing abortion as a "control of pregnancy" through historical, religious, moral, and statistical analyses).

${ }^{120}$ Id. at 287-88.

${ }^{121}$ See Cornell, supra note 114, at 363 ("She is forced to give birth and be a mother.").

${ }^{122}$ Id.
} 
other to our body." ${ }^{123}$ While the sexual act in S.F. was not a typical assault (S.F. was unconscious), there was still a violent invasion of his body. Upon waking, he must have realized that his body had been used without his consent or even his awareness; this is an example of a separation from one's own body or seeing one's own body as other than oneself. Turning to the sexual nature of this assault, there are connections between bodily integrity, consent, and sexual autonomy that have been explored in the context of female victims of sexual wrongdoings. Jane Larson, in a feminist analysis of seduction and tort law, states that, when "sexual consent is coerced, whether by force or fraud, the result is nonconsensual sex, a moral and physical dispossession of one's sexual body." ${ }^{24}$ Larson begins her argument with "the premise that sexual fraud leads to nonconsensual sex because it deprives the victim of control over her body and denies her meaningful sexual choice." ${ }^{, 25}$ Thus, the body that is being invaded is a sexual body, and the necessity for "coherence and self-control"126 is magnified. Larson then describes autonomy as a feminist value, one that encompasses "three constituent aspects-bodily integrity, sexual selfpossession, and sexual self-governance." ${ }^{27}$ This conception of autonomy may thus be seen as expanding and embracing the feminist notion of bodily integrity. When applied to S.F., it is clear that Larson's call for "consent as a means and sexual autonomy as the end of a feminist sexual politics" ${ }^{, 128}$ could aptly be applied to the strict liability of sperm, at least in cases of male victims of sexual assault. ${ }^{129}$ The S.F. court, instead of merely invoking the "legal and moral duty"

123 Id. at 346.

${ }^{124}$ Jane E. Larson, "Women Understand So Little, They Call My Good Nature 'Deceit'”: A Feminist Rethinking of Seduction, 93 COLUM. L. REV. 374, 420 (1993).

${ }^{125}$ Id. at 380.

${ }^{126}$ Cornell, supra note 114, at 362 ("The image necessary for personhood is that of coherence and self-control.").

${ }^{127}$ Larson, supra note 124 , at 425.

128 Id. at 424.

${ }^{129}$ Larson herself addresses cases involving male plaintiffs. See id. at 407 ("Surprisingly, although emotionalism is stereotypically associated with women, male plaintiffs have brought the majority of emotional injury claims in the reported sexual fraud case law."). Nonetheless, she dismisses the significance of the male plaintiffs' claims because of the third-party interests of the child. See id. at 409 ("In the unwanted parenthood cases, courts limit sexual fraud liability to uphold a public policy of protecting children."). I discuss below why this use of the purported interests of the child is itself problematic. See infra Part II.B (discussing the conflict between the best interests of the child standard and the strict liability of sperm). It would be interesting to see how Larson would apply her theory of sexual politics to the men in these cases.

${ }^{130}$ S.F. v. State ex rel. T.M., 695 So. 2d 1186, 1188 (Ala. Civ. App. 1996). 
parents to care for their children, also could have addressed S.F.'s claims of sexual assault. By devaluing the significance of the sexual assault, the court sent the message that it is not willing or able to protect male sexual autonomy.

Nathaniel J. presents similar questions, and the feminist ideals of bodily integrity, ${ }^{131}$ consent, and sexual autonomy lead one to challenge the applicability of the strict liability theory to statutory rape victims. Here the idea of consent is complicated by the fact that the law does not grant Nathaniel J. the power to consent, yet the court based his liability at least in part on the fact that he actually agreed to the sexual relations. ${ }^{132}$ Britton Guerrina presents the various means by which statutory rape defendants are able to bring in evidence of a victim's sexual history, reputation, and behavior leading up to, and during, the act in question. ${ }^{133}$ The policy goals of statutory rape laws (essentially protecting the victims from themselves, as well as preventing teenage pregnancy) are supported by evidence that " $[y]$ oung adolescents who engage in sexual activity with adults may experience longterm emotional scars that impair their sexual and romantic relationships as adults." ${ }^{134}$ Guerrina argues that using a female's aggressive sexual behavior as a measure of her maturity is antithetical to these policy concerns ${ }^{135}$ and improperly diverts the fact-finder's attention from the perpetrator's behavior to that of the victim. ${ }^{136}$ Further, to mitigate the punishment for these crimes both encourages this type of behavior amongst men and reinforces the idea of an "irrepressible [male] sex drive[]" that is to be tempered by the more chaste sex. ${ }^{137}$

${ }^{131}$ As mentioned earlier, the idea of protection for bodily integrity has been supported by the Supreme Court, which is not considered, by most standards, to be a feminist institution. Supra note 114.

${ }^{132}$ Nathaniel J., 57 Cal. Rptr. 2d 843, 845 (Ct. App. 1996).

${ }^{133}$ Britton Guerrina, Comment, Mitigating Punishment for Statutory Rape, 65 U. CHI. L. REV. 1251, 1257 (1998).

${ }^{134} I d$. at 1261 .

${ }^{135}$ See id. at 1267 ("A girl's sexually provocative conduct is often not a valid proxy for maturity; a girl may behave provocatively and still be unable to make informed decisions about sex.”).

${ }^{136} I d$. at 1269 .

${ }^{137} I d$. at 1270-71. This notion of the irresponsible male has also come up in Supreme Court sex discrimination jurisprudence. Justice Sandra Day O'Connor's dissent in Nguyen v. I.N.S., 533 U.S. 53, 94 (2001) (O'Connor, J., dissenting), illustrates that at least some justices on the Court are aware that the problem of gender stereotypes extends to both men and women: "Indeed, the majority's discussion may itself simply reflect the stereotype of male irresponsibility that is no more a basis for the validity of the classification than are stereotypes about the 'traditional' behavior patterns of women." Id. 
Notions of male irrepressibility and female chastity are invoked in Nathaniel J.'s case, in spite of the fact that the female is the perpetrator. ${ }^{138}$ Here, the court upholds these traditional notions notwithstanding the male gender of the victim by crediting Nathaniel J.'s apparent desire and discrediting any possible harm to him as an adolescent. Although Guerrina's article focuses almost exclusively on female victims of statutory rape, I argue that a feminist approach to this case would also find the mention of Nathaniel J.'s willingness and enjoyment of the sexual experience problematic. The focus clearly was shifted away from his partner in the sexual act (the perpetrator, according to criminal law) to his own conduct. It is telling that the court did not discuss the female's role in the situation, which might have revealed her power and influence over Nathaniel J. The idea of the female sexual aggressor is difficult both for courts (upholding traditional views) and for many feminist thinkers because it disrupts the standard conception of gender and power embedded in the work of such theorists as Catharine MacKinnon. ${ }^{139}$ Focusing on the victim's conduct obscures the fact (perhaps even more obvious in S.F.) that Nathaniel J., by virtue of his age, was deprived of meaningful consent and sexual autonomy.

\section{The Fluidity of Masculinity}

Just as it is important to apply Guerrina's ideas to male as well as female victims, it is important for feminist thinkers to analyze the ways that these laws maintain stereotypes of both men and women. The application of the law indicates static and rigid understandings of gender and sex, which is contradictory to yet another feminist ideal: the conception of gender as a fluid and socially constructed category. ${ }^{140}$ Applying this idea to these cases requires an acknowledgment that masculinity, as well as femininity, is neither monolithic nor

${ }^{138}$ Nathaniel J., 57 Cal. Rptr. 2d 843, 844 (Ct. App. 1996).

139 CAtherine MacKinnon, Feminism Unmodified (1987). MacKinnon's power/ dominance paradigm is not uncontested by scholars, but it has been highly influential in the legal world. She describes her approach to gender and equality as follows: "Gender is ... a question of power, specifically of male supremacy and female subordination.... Gender might not even code as difference, might not mean distinction epistemologically, were it not for its consequences for social power." Id. at 40. Her dominance approach "sees the inequalities of the social world from the standpoint of the subordination of women to men," $i d$. at 43 , and offers a way to confront the "systematic regulation of an entire group of people to a condition of inferiority and attribute it to their nature," $i d$. at 41.

${ }^{140}$ See, e.g., SCOTT, supra note 7, at 28 (discussing the historical feminist use of the term "gender" and how it is related to social constructions and power dynamics). 
static. ${ }^{141}$ Fluidity is a central premise of the developing academic field of masculinity studies, in which scholars are using various critical approaches to rethink or expand upon feminist scholarship. ${ }^{142}$

Susan Bordo's exploration of the male body in the context of popular culture provides some useful tools of analysis for the cases at hand. ${ }^{143}$ She explains, for example, that boys (and men) that are abused or embarrassed will "turn to their bodies in an attempt to establish a private domain in which a sense of control and self-esteem can be reestablished." ${ }^{144}$ Whereas young women often diet to regain control of their lives (via their bodies), young men very often turn to bodybuilding. These activities—both for girls and for boys-are not merely related to "looking good." Rather, they are concerned with "developing a body that makes one feel safe, respected, in control."145 This connects directly to the above discussion regarding bodily integrity by illustrating the equal vulnerability of the male body as compared with the female body. The example of bodybuilding demonstrates that men also face societal pressures that are then reflected in their conception of their physical selves. It follows that male bodies are just as much in need of legal protection as are female bodies. ${ }^{146}$

Bordo describes a "double bind of masculinity" ${ }^{\text {"147 }}$ that our culture imposes on males. Males (especially those involved in athletics) are actively encouraged to be aggressive, but they are also taught that they are to stop immediately upon hearing the word "no" from a woman. ${ }^{148}$

${ }^{141}$ Judith Kegan Gardiner, Introduction to MASCULINITY STUDIES AND FEMINIST ThEORY: NEW DiRECTIONS 11 (Judith Kegan Gardiner ed., 2002). "Feminist-inflected masculinity studies have reached consensus about some previously troubling issues. Chief among these is the initial insight that masculinity, too, is a gender and therefore that men as well as women have undergone historical and cultural processes of gender formation that distribute power and privilege unevenly." Id.

${ }^{142}$ See, e.g., Alan Petersen, UnMasking the Masculine: 'Men' AND 'IDENTITY' IN A SCEPTICAL AGE 3 (1998) (outlining briefly some of the various critiques of this academic approach, including strong criticisms from feminists). Petersen's starting premise for his work is that "'masculinity' has been essentialised and that this has provided a major impediment to theoretical and political work." Id.

${ }^{143}$ See BORDO, supra note 112, at 55-59 (connecting, for instance, media stories about Bill Clinton's "doughy physique" with a concern that he was "unpresidential" in contrast to the image of Ronald Reagan on horseback and generally relating physical fitness with the desire for emotional toughness).

${ }^{144} I d$. at 57.

${ }^{145} \mathrm{Id}$.

${ }^{146}$ See the discussion of Drucilla Cornell, supra notes 114-18 and accompanying text, for a description of the importance of bodily wholeness to developing and preserving self-identity.

${ }^{147}$ BORDO, supra note 112, at 242.

${ }^{148}$ Id. at 234. 
The dichotomy is presented as animal versus gentleman, and Bordo asserts that this is confusing and even paralyzing for men who are trying to form their sexual identity as well as their gender identity. ${ }^{149}$

This double bind is apparent with the male victims of statutory rape or sexual assault, a case in which the requirements of aggression and politeness are complex and often conflicting. First, there is the stigma of being a victim (especially in the sexual context), which, simply by admitting victimization, shows weakness in the male plaintiff. ${ }^{150}$ But a man may assert this victimization in the guise of a legal defense (thus making it aggressive rather than passive) against paying child support for an unintended and unwanted child, placing the emphasis on the financial aspects and overall unfairness of the situation rather than on any psychological or emotional harm stemming from the sexual assault. Men who resist paying child support, however, are then in danger of being characterized as the "deadbeat dads" (perceived not only irresponsible but also uncaring) ${ }^{151}$ against whom the law is really aimed. Fathers' rights groups deal with the question of masculinity in a careful way, in large part due to this "double bind." For example, the Fathers' Rights and Equality Exchange (F.R.E.E.) establishes itself as both assertive (as to legal rights) and compassionate (as to the plight of single mothers):

To be sure, F.R.E.E. recognizes that there are indeed some fathers who don't pay support, or who skip town. However there are a great many fathers who want to parent their children, who are willing and prepared to pay their fair share of child-support, and who wish only to be treated with respect, fairness, and dignity by the State, the Family Law System, and by society. It is these fathers for whom F.R.E.E. stands up and advocates. ${ }^{152}$

${ }^{149} I d$. at 241 ("The thoughtful, intelligent, caring boy-one who is least likely to behave disrespectfully with a girl-may find himself paralyzed, caught between his desire to act 'like a man' and fear of giving offense.").

${ }^{150}$ See id. at 55 (discussing the male fear of being perceived as "soft" and weak).

${ }^{151}$ The Fathers' Rights and Equality Exchange (F.R.E.E.) works to destigmatize fathers as a group, and in doing so the organization notes the "myth of the 'deadbeat dad"' as a major obstacle:

Perhaps no other group suffers as much stigma and public scorn than absent and separated fathers. There is a destructive myth that pervades society centered around a character called the 'deatbeat dad.' [sic] This largely mythical beast stashes money and assets in offshore investments, hob-nobs with friends at the country club, and jets off to St. Moritz ... while mom and the kids languish on AFDC at taxpayers' expense.

Fathers' Rights \& Equality Exchange, DadsRight.org, Myth America: "The Myth of the 'Deadbeat Dad'", at http:/ /www.dadsrights.org/myth.html (last visited Apr. 30, 2004).

${ }^{152}$ Fathers' Rights \& Equality Exchange, Mission Statement, at http://www.dads rights.org/mission.html (last visited Apr. 30, 2004) (emphasis omitted). 
Groups such as F.R.E.E. seem to be aware of their strange position in a space both within and between traditional notions of masculinity and feminism. F.R.E.E. attempts to navigate the double bind and to accommodate contrasting ideals by simultaneously emphasizing that its members are good, caring parents to their children, but also that they are no longer going to be intimidated and are ready to fight back in the legal arena. ${ }^{153}$

In addition to examining changing notions of masculinity in cultural or historical terms, some scholars note that a person's gender identity also changes over the course of an individual's lifetime. Judith Kegan Gardiner, for example, examines the categories of age and gender, and asserts that age categories may be useful to depolarize the typically binary discourse of gender analysis. ${ }^{154}$ Age categories are continuous rather than dichotomous, and if imposed on gender categories, may thus encourage more flexible thinking. ${ }^{155}$ Age, like gender, is tied to biological characteristics, but it is also constructed by social influences and an individual's reaction to, and incorporation of, such influences. Another similarity between the two categories is the complex power dynamic involved, although it may be easier to note differential power relations in comparing two people at different stages in life than in the context of gender. ${ }^{156}$ This is because gender power differentials are often more contested and more subtle, whereas there is more general acceptance of the power differentials between children and adults, for example. Feminists are now doing scholarly work on the developmental stages of female identity, ${ }^{157}$ and corresponding (and complementary) work on the development of masculinity in individuals' lives would be useful to the critique of the strict liability standard. This is especially relevant in the context of the statutory

153 See, e.g., Fathers' Rights \& Equality Exchange, Fathers and the Political Process, at http://www.dadsrights.org/legis.html (last visited Apr. 30, 2004) (acknowledging the "overwhelming sense of powerlessness" felt by many recently divorced fathers and focusing on "empowering dads to affect the political process").

${ }^{154}$ Judith Kegan Gardiner, Theorizing Age with Gender: Bly's Boys, Feminism, and Maturity Masculinity, in MASCUlinity STUdies \& Feminist Theory: NeW DiRections 90, 91 (Judith Kegan Gardiner ed., 2002).

${ }^{155} I d$. at 94 .

${ }^{156}$ Gardiner writes that

it is perhaps clearer in the case of age than of gender that the common categories used to describe them continually slip back and forth between descriptions of typical behavior and prescriptions for how people should be and behave, with a wide range of material consequences meted out to those who deviate from the behaviors considered proper for each group. Id. at 97 .

${ }^{157}$ See id. at 99 (reviewing recent studies). 
rape cases, as this scholarship could produce increasingly subtle thinking about male victimization as specific to the age of the victim. Thus, if the Nathaniel J. court had considered more seriously the implications of Nathaniel J.'s age, it might have concluded that his identity as a male and as a sexual being were at a critical stage of development-a vulnerable adolescent period requiring legal and other protection.

There is direct evidence of the impact of these ideas on people's lives, as seen in the inability of societal institutions to address the problem of male victims of sexual abuse. By upholding gendered stereotypes and ignoring the very real injuries suffered by the male plaintiffs in these cases, the law is further silencing the already understudied problem of sexual abuse of men and boys. There are several problems related to the reporting and handling of male sexual victimization, including a fear of stigma (of homosexuality and/or weakness) and the inability or unwillingness of medical centers, law enforcement centers, families, and peers to help the victims. ${ }^{158}$ Even some rape crisis centers have been unreceptive to helping male victims of sexual abuse. ${ }^{159}$ Just as feminists work to actively address the problems of sexual violence toward females, we cannot blind ourselves to the damage caused by ignoring male victims.

Another reason to apply feminist ideals to these cases is to strengthen a political position. While the fathers' rights groups may appear to be on the fringe, they are critical in highlighting the problems in these cases. It is ironic that these groups may be able to alert feminists to the contradictions at hand; perhaps even stranger still is the fact that feminists may share their ultimate goals. If feminists are willing to acknowledge the inadequacy of the current system, space could be opened up for a coalition encompassing a vast political spectrum in its condemnation of traditional thinking. In the context of statutory rape, sexual assault, and even contraceptive fraud, addressing the problem of strict liability in child support determinations need not mean abandoning mothers and their children; rather, being open to questioning these cases and others could serve as a catalyst for rethinking the impact of the discourses on both men and women. At that point, there would be space for innovative thinking and a deeper

${ }^{158}$ See Nicholas L. Marsilio, Voices Reclaimed: Male Victims of Sexual Violence 5 (2002) (unpublished B.A. thesis, Pennsylvania State University) (on file with author) (discussing the beliefs of institutional actors that make reporting difficult).

${ }^{159}$ See id. at 5 ("It is surprising to find that the other group least responsive to male victims are feminist-based rape crisis centers."); see also Patricia A. Washington, Second Assault of Male Survivors of Sexual Violence, 14 J. INTERPERSONAL VIOLENCE 713, 727-28 (1999) (discussing the shortcomings of predominantly feminist-oriented approaches). 
questioning of the welfare and family law system, questioning that is, in fact, much needed. ${ }^{160}$

\section{B. The Best Interest of the Child and the Strict Liability Theory of Sperm}

Both the S.F. and Nathaniel J. courts cited the interest of the child as the central concern-an interest that clearly trumped any claims made by the male victims. ${ }^{161}$ The concern is not merely financial, but also seeks to ensure that there are specifically two biological parents contributing to the child's needs. In Nathaniel J., the court noted that not only is every child entitled to a certain amount of minimum support, but that this support must come not from one parent, or one parent and the state, but from both the biological mother and the biological father. ${ }^{162}$ This illustrates what has been termed the "two-parent model," which is based upon a married heterosexual couple and their children. ${ }^{163}$ Through the use of strict liability in both decisions, we see the court extending this two-parent model to the nonmarital couple and their child as well. ${ }^{164}$ Although there are certainly real economic

${ }^{160}$ Many thinkers have challenged the current structure and underlying assumptions of the welfare system, including Martha Fineman. See Martha ALbERTSOn Fineman, The Neutered Mother, The Sexual Family and Other TwentiethCENTURY TRAGEDIES 113-14 (1995) (discussing the patriarchal underpinnings of current policy). Another problem that some scholars have addressed is the lack of concern in federal courts for issues of gender and family. See, e.g., Judith Resnik, "Naturally" Without Gender: Women, Jurisdiction, and the Federal Courts, 66 N.Y.U. L. REV. 1682, 1697 (1991) (looking at the ways in which "women's roles in the family are not much a part of the national issues to which federal court resources should be dedicated"); Michael Ashley Stein, The Domestic Relations Exception to Federal Jurisdiction: Rethinking an Unsettled Federal Courts Doctrine, 36 B.C. L. REV. 669, 670 (1995) ("Underlying these disagreements is a complex and unresolved debate over the proper role of federal courts in adjudicating a substantive area of law traditionally considered within the exclusive purview of state courts.").

${ }^{161}$ See S.F. v. State ex rel T.M., 695 So. 2d 1186, 1189 (Ala. Civ. App. 1996) ("Therefore, in proceedings brought pursuant to this act, the interests of the child are our paramount concern and take precedent over the interests of the other parties involved."); County of San Luis Obispo v. Nathaniel J., 57 Cal. Rptr. 2d 843, 845 (Ct. App. 1996) ("This State's interest in requiring minor parents to support their children overrides the State's competing interest in protecting juveniles from improvident acts, even when such acts may include criminal activity on the part of the other parent." (quoting State ex. rel. Hermesmann v. Seyer, 847 P.2d 1273, 1279 (Kan. 1993))).

${ }^{162}$ See 57 Cal. Rptr. 2d at 844 ("California law provides that every child has a right to support from both parents.").

${ }^{163}$ See Marsha Garrison, Law Making for Baby Making: An Interpretive Approach to the Determination of Legal Parentage, 113 HARV. L. REv. 835, 882-89 (2000) (describing a familial model that is often used to justify public policy).

${ }^{164}$ See id. at 886-89 (explaining the broader shifting of this model to the separated family through initiatives such as parent education programs aimed at divorced couples). 
concerns underlying this policy, ${ }^{165}$ it is based in large part on the belief that children of single-parent families are worse off in many respects than their counterparts who have both a mother and a father who are active participants in their lives. ${ }^{166}$ There is, in fact, a "growing consensus that it is "the right of every child ... to have the ties of nature maintained, wherever possible, with the parents who gave it life." "167

The rhetoric of the "best interest of the child" is certainly compelling, and it is easy to see why policymakers, courts, and theorists often accept it as the only equitable solution to complicated family situations. As many scholars have illustrated, however, on closer examination this rhetoric proves to be simplistic and even anathema to many leftist ideals; it is deeply intertwined with conservative moral notions of family and gender. Jones discusses the two-parent justification in terms of the statutory rape cases, and she points out that the source of the child's rights in these cases has already been shifted to the state: ${ }^{168}$

The court is not being asked to render an innocent child destitute. Thus, the issue in the child support-statutory rape cases is not whether it is in the best interests of the child to receive financial support from the biological parent, even though the parent has been sexually victimized. Rather, the issue is whether it is in the best interests of the child to have the sexually victimized biological parent reimburse the state for public funds paid to his child via the AFDC or TANF programs.

She concludes that the demand for child support from the father in these cases can best be characterized as a "proxy for a demand for greater general parental responsibility."170

Thus, the state is promoting morality in addition to the child's economic well-being through the guise of these child support payments. Even though a direct connection between legally enforced payments and quality parental relationships is tenuous at best, ${ }^{171}$ this is

${ }^{165}$ Specifically, a concern for bringing much-needed financial resources to many low-income single mothers.

${ }^{166}$ See Garrison, supra note 163, at 887 (citing evidence stating that although being low-income is the most important factor for the negative consequences faced by children of single parents, "lower quality parent-child relationships that result from parental conflict, stress, and absence, also play a role").

${ }_{167}$ Id. at 888 (quoting In re K., [1990] 1 W.L.R. 431, 437 (C.A. 1990)).

${ }^{168}$ Jones, supra note 98 , at 449-50. The cases often are initiated by the county, not by the mother, as the county seeks repayment for public benefits distributed to the mother.

${ }^{169} I d$.

${ }^{170} I d$. at 451 .

${ }^{171}$ Jones cites research indicating that children may be better situated with two parents, but then she wonders why the courts in statutory rape cases only require the 
a way for the state to create a marital model where none exists. Martha Fineman, a prominent feminist legal scholar, maintains that "[1] egal attachment of men to women and children is the popular panacea for many social ills ... and marriage is seriously offered as the appropriate social policy." She argues that child support payments are connected to a belief that the private family unit is capable of solving such social problems as child poverty (and all of the resulting social ills that are subsequently traced to child poverty). ${ }^{173}$ This belief is based on an assumption that the private family is self-sufficient ${ }^{174}$ because the private family envisioned by conservatives is not one that relies on state support. Such a family unit is traditional in that it requires a father/husband figure and a mother/wife figure. ${ }^{175}$ Fineman

father to make monetary payments, but do not address "the child's legitimate need for an emotional and physical relationship with the biological father by making custody or visitation decisions." Id. at 452. She points out that courts can require child support payments even in cases in which they cannot force the father to uphold other parental responsibilities. Id. at 453. Also, while some studies do show that support payment leads to more regular visitation, other studies involving unwed fathers "specifically show that other variables impact whether an unwed father will have a relationship with his child." Id.

${ }^{172}$ Martha Albertson Fineman, Child Support is Not the Answer: The Nature of Dependencies and Welfare Reform, in CHILD SUPPORT: THE NEXT FRONTIER, supra note 26. But cf. Michelle Conlin, UnMarried America, Bus. WK., Oct. 20, 2003, at 106 (citing recent statistics that indicate that marriage is "on the wane"). Michelle Conlin's article cites the U.S. Census Bureau as showing that married-couple households now make up only $50.7 \%$ of the population today, as compared with almost $80 \%$ merely fifty years ago. "Already, unmarrieds make up $42 \%$ of the workforce, $40 \%$ of home buyers, $35 \%$ of voters, and one of the most potent-if pluralistic-consumer groups on record." Id. at 106. Interestingly, these numbers are counterintuitive to a recent "infatuation" with the institution of marriage, as seen in the government (Bush's marriage-promotion campaign to counteract the rising arguments for gay marriage, for example) and in popular culture (as in reality television shows based on marriage). Id. at 106-08.

${ }^{173}$ See Fineman, supra note 172, at 215 ("As a functional matter, the natural family is ideally a private family — the social institution that will raise the children ....").

${ }^{174}$ Fineman also notes that " $[\mathrm{t}]$ he resort to marriage and the traditional family as a reformist ploy is grounded in the myths of autonomy, independence, and selfsufficiency that represent ideals for families as well as individuals." Id.

${ }^{175} \mathrm{See} i d$. ("[S] ociety gravitates toward the family populated in traditional form: husband/father, wife/mother, and dependent/minor children.”). The tradition of a male/female-headed household is also reflected in the gay marriage debate. The dissenting opinion in Goodridge v. Dep't of Public Health states that "[i]n this Commonwealth and in this country, the roots of the institution of marriage are deeply set in history as a civil union between a single man and a single woman." 798 N.E.2d 941, 977 (Mass. 2003) (Spina, J., dissenting). There are also those who would argue that the traditional heterosexual union is based on more than tradition. Andrew Koppelman analyzes (and rejects) the claims of the "new natural law theorists" who argue that "marriage is a communion of persons that can only be consummated and actualized by sexual acts of the reproductive type." Andrew Koppelman, Sexual Morality and the 
claims that the private family cannot and should not be held solely responsible for the care of children and that the problems raised in connection with child support are linked to the need for broader changes in society's conception and treatment of maternity and work. ${ }^{176}$ Jones makes a similar point in examining the "private responsibility model of public benefits," a model that works to maintain the private family as the source of all child support rather than the state. ${ }^{177}$ She concludes that even if the system in general is not changed, "a male statutory rape victim's status as a victim is a sufficient reason for the state to bear the cost of supporting a child resulting from statutory rape." ${ }^{\prime 178}$ Jones seeks a solution for a discrete issue, and Fineman believes that the entire system is in need of serious reform. Through two separate analyses, both agree that the strict liability standard for child support and the "best interests of the child" discourse represent something greater than the actual needs of the child in any given case.

The motivations behind the law-to favor a traditional marital and parental relationship through its policies-may be impractical, ${ }^{179}$ but these motivations are also theoretically problematic for those who do not fit within this traditional model (such as women who choose to be single mothers), and even for some who do. The idea of "responsible reproduction" is a central theme of the "family-values" discourse (put forth by conservatives in recent years), and its message is that responsible reproduction occurs within the context of a marriage ${ }^{180}$ The gender stereotyping and categorization that was discussed with regard to the strict liability standard is present in these underlying policies as well. For example, conservatives are disturbed by the idea of women seeking parenthood without male involvement, and Fineman argues that there is a resulting "need to 'discipline' those women who do not conform to roles associated with the traditional family but rather live

Possibility of "Same-Sex Marriage": Is Marriage Inherently Heterosexual? 42 AM. J. JuRIS. 51, 52 (1997).

${ }^{176}$ See Fineman, supra note 172, at 215-20.

${ }^{177}$ Jones, supra note 98 , at 454-57.

${ }^{178} I d$. at 456.

179 See supra notes 166-67 (discussing the use of child support as a means to encourage quality relationships and the lack of a connection between making monetary payments and fostering a parent-child bond).

${ }^{180}$ See Fineman, supra note 172, at 221 ("The message is that responsible reproduction ... occurs only within the context of the traditional family."); Linda C. McClain, "Irresponsible" Reproduction, 47 HASTINGS L.J. 339, 340 (1996) ("The cluster of behaviors and choices that have been labelled 'irresponsible' includes, but is not limited to, 'illegitimacy,' single-parent families, divorce, abortion, and adolescent sexual activity."). 
outside the hierarchical, patriarchal family."181 In the same vein, a man who does not want to pay child support for a child that is biologically his (not to mention a man who chooses to resist the marital relationship) must face charges of being a "deadbeat dad," the ultimate irresponsible reproducer. ${ }^{182}$

The responsible reproduction model also fails to account for the complex position of marriage today, as it is simultaneously denigrated and applauded. No matter which side of the debate one supports, it is clear that marriage occupies a contested political space in the national consciousness. ${ }^{183}$ One of the clearest problems is that lesbian and gay families, as well as any other nontraditional families, historically have been excluded legally. ${ }^{184}$ Susan Apel also paints a dire portrait of the marriage institution for women, citing the high rates of abuse in marriages as well as economic and legal inequities and the general daily burdens faced by married women. ${ }^{185}$ Fineman offers similar evidence, remarking that the "nature and extent of private violence calls into

181 Fineman, supra note 172 , at 221.

182 See McClain, supra note 180, at 345 (discussing various models of irresponsible male reproduction, which include "single fathers," "deadbeat dads," and " promiscuous' or "predatory' males"). While there is great concern over the choices that women are making, Linda McClain also points out that "some who sound the alarm about single-parent families perceive the crisis in terms of 'fatherless America' and of men's abandonment of the role and responsibilities of fatherhood." Id. at 341.

${ }^{183}$ See, e.g., Conlin, supra note 172 (exploring the role of marriage in today's society). The recent debates over gay marriage have only reinforced its tenuous position. See, e.g., Mehren, supra note 18 (describing the debate in Massachusetts and how the court, the legislature, the religious establishment, and the people of Massachusetts are deeply divided over this issue).

${ }^{184}$ The rhetoric of the examined cases endorses not only the notion that the child deserves support from two parents, but also that these two parents will be of the opposite sex. For example, the Nathaniel J. court noted that in California "the father and mother of a child bear 'equal responsibility' to support the child." Nathaniel J., 57 Cal. Rptr. 2d 843, 844 (Ct. App. 1996). The assumption is that there will always be a man and a woman who will share parenting duties. Nontraditional families can respond by either rejecting this notion (for some of the reasons outlined above) or by trying to attain access to marital status. The gay rights community is grappling with this tension, as advocates for marriage rights within the gay community must justify why marriage is an institution to which all should aspire. The Massachusetts Supreme Judicial Court recently weighed in on the debate, stating that:

Marriage is a vital social institution. The exclusive commitment of two individuals to each other nurtures love and mutual support; it brings stability to our society. For those who choose to marry, and for their children, marriage provides an abundance of legal, financial, and social benefits. In return it imposes weighty legal, financial, and social obligations. Goodridge v. Dep't of Pub. Health, 798 N.E.2d 941, 948 (Mass. 2003).

${ }^{185}$ See Susan B. Apel, Communitarianism and Feminism: The Case Against the Preference for the Two-Parent Family, 10 WIS. WOMEN'S L.J. 1, 4-19 (1995) (exploring the reasons why marriage is a problematic and even dangerous institution for women). 
question the wisdom of policies designed to coerce women to stay with male partners to avoid poverty and governmental censure." 186 Marriage also seems to have failed at the one thing that policymakers expected of it-its role as a stable economic institution capable of supporting its dependents. ${ }^{187}$ Finally, the most damaging evidence against marriage for both women and men may be the oft-cited divorce rate in the country today, indicating that marriage may not prove to be entirely viable to the very people involved. ${ }^{188}$ The problems of divorce and the resulting interests of the children of divorced parents are often ignored by traditionalists in discussing issues related to child support because it is easier to focus on the irresponsible reproduction of illegitimacy. $^{189}$

Finally, the best interest of the child and underlying responsible reproduction rhetoric have been challenged at the most basic level, namely as to whether or not these policies really are best for the children themselves. ${ }^{190}$ Nancy Polikoff, arguing that women should be free to form families without men, reframes the issue:

[I begin] with the premise that it is no tragedy, either on a national scale or in an individual family, for children to be raised without fathers. Children raised without love and guidance, without shelter, nutrition,

${ }^{186}$ Fineman, supra note 172, at 216.

${ }^{187}$ See id. at 216-17 ("Given a variety of market realities, the breadwinner/housewife model is not an institution that can adequately take care of dependency.").

${ }^{188}$ See id. at 216 ("The U.S. Bureau of the Census estimates that half of all marriages entered into since 1970 could end in divorce.”). A study based on data collected in 1995 showed that about half of all first marriages end in divorce within twenty years. MATTHEW D. BRAmlett \& William D. MOSHER, CTRS. FOR Disease CONTROL AND Prevention, Nat'l Ctr. For Health Statistics No. 323, Advance Data: First Marriage Dissolution, Divorce, ANd Remarriage: United States 6 (May 31, 2001), available at http://www.cdc.gov/nchs/data/ad/ad323.pdf. But see Sally C. Clarke, Ctrs. for Disease Control and Prevention, Advance Report of Final Divorce Statistics, 1989 and 1990, 43 Monthly Vital Statistics Report No. 9, at 9 (Supp. 1995) (showing steady decline in divorce rate since 1981).

${ }^{189}$ See McClain, supra note 180, at 362-63. McClain writes that:

One might credibly argue that 'illegitimacy' is an easier target than divorce because the former is viewed as behavior more typical of 'others' (namely, poor people and people of color), while the latter implicates many middleclass and upper-class American lives (including those of prominent proponents of the attack on 'illegitimacy' and welfare dependency).

Id.

190 See Apel, supra note 185, at 19-22 (arguing that children may be better off in a single-parent home rather than in a two-parent home full of conflict and on the verge of divorce). 
and health care, without meaningful education, without physical safety in their homes and on their streets- that is tragic. ${ }^{191}$

This underscores Marsha Garrison's assertion that the very real concern of child poverty cannot be solved through the current child support system: "Policymakers simply must accept the fact that child support policy cannot substitute for an antipoverty program., ${ }^{192}$

\section{LEAVING BEHIND THE STRICT LiABILITY ThEORY: SOME SUGGESTIONS FOR CHANGE}

\section{A. Applying Theory: A Call for (Feminist-Led) Action}

The Massachusetts Supreme Judicial Court noted that its recent historic ruling on same-sex marriage "marks a change in the history of our marriage law." ${ }^{193}$ Even the courts, so slow to deviate from the status quo, ${ }^{194}$ will facilitate dramatic political and social change when necessary. ${ }^{195}$ The battle over same-sex marriage is forcing the legal system-and the country as a whole-to reevaluate definitions of family, as well as of gender, sexuality, and child-rearing. At the same time, the late-term abortion issue is mobilizing feminists and the Left to fight not only this law, but also to counter widely accepted prolife rhetoric. $^{196}$ This is a moment for feminists to seize upon such victories as Lawrence v. Texas ${ }^{197}$ and Goodridge v. Department of Public Health ${ }^{198}$ to force courts to continue to adapt to changing social perceptions. In taking these next steps, feminists and Left thinkers have a unique opportunity to rethink their positions and assumptions, just as Brown

${ }^{191}$ Polikoff, supra note 11 , at 375 .

${ }^{192}$ Garrison, supra note 26, at 31.

${ }_{193}$ Goodridge v. Dep't of Public Health, 798 N.E.2d 941, 948 (Mass. 2003).

194 See, e.g., Trammel v. United States, 445 U.S. 40, 48 (1980) (“[W]e cannot escape the reality that the law on occasion adheres to doctrinal concepts long after the reasons which gave them birth have disappeared and after experience suggests the need for change.").

${ }^{195}$ The San Francisco Superior Court recently did so in refusing to put an immediate end to same-sex marriage licenses being issued in the city. Murphy, supra note 18 .

196 See supra note 10 (citing news reports on opposition to the law).

${ }^{197}$ See Lawrence v. Texas, 123 S. Ct. 2472, 2484 (2003) (holding that a Texas statute criminalizing same-sex sexual conduct was a violation of the Due Process Clause of the Fourteenth Amendment).

198 See Goodridge, 798 N.E.2d at 948 (concluding that the denial of marriage to same-sex couples is a violation of the Massachusetts Constitution); see also Opinions of the Justices to the Senate, 802 N.E.2d 565 (Mass. 2004) (advising the legislature that civil unions would not be sufficient and that full and equal marriage rights are required by the Massachusetts Constitution). 
and Halley urge us to do. ${ }^{199}$ It is a chance to look at cases such as S.F. and Nathaniel J. with a more critical eye and to admit that they are a problem not so easily resolved.

These are cases in which men were victims of sexual abuse according to the law and were then required by the law to provide child support payments for the child conceived during the incident of abuse. This is a system that ignores the tremendous impact sexual victimization has on an individual's life. Its uniformly applied solution of putting the child's alleged "best interests" above the interests of the male victim serves to further divert attention from the very issue of the victimization. The law must be honest in facing the sexual dynamics in such cases; it must not be allowed to hide behind the rhetoric of protecting children. Feminists and others concerned with gender will have to ensure that the legal system is forced to answer to these charges and to change. Feminist thinkers have been successful in achieving widespread legal change in past decades, and they certainly have the power to address this issue now. To concentrate on male victims is not to abandon feminism; rather it is to take a much-needed step toward a more effective understanding of equality and sex.

Feminists such as Drucilla Cornell ${ }^{200}$ articulate the centrality ofand need for-bodily integrity, and with abortion rights at a critical juncture, these ideas should be further developed and explored. If bodily integrity is an essential value for feminists-which it is and should be-it must be protected for men as well as for women. S.F. was sexually assaulted while unconscious and was deprived of consent to the sexual and procreative use of his own body. Nathaniel J. was only 15 when he impregnated his sexual partner, and, yet, the court assumed that he had the maturity to consent to sex with a 34-year-old woman and that he understood the risks that he was taking. If these two individuals had been female, the court would most certainly have treated them differently, in accordance with traditional notions of female victimization. ${ }^{201}$ Current understandings of bodily integrity and sexual autonomy are clearly inadequate to address these cases, as they focus on the unique nature of the female body. If we accept the idea that gender and sexuality are fluid and relational, then legal scholarship and policy on women must also take men into account and not treated simply as dominant and aggressive. The male body is also a

\footnotetext{
${ }^{199}$ See supra text accompanying notes 12-14 (characterizing these scholars' views).

${ }^{200}$ See supra text accompanying notes 114-18 (summarizing Cornell's analysis).

${ }^{201}$ See supra note 88 (describing how courts treat female victims of sexual assault more compassionately than they treat male victims).
} 
site of identity formation, social pressure, and vulnerability, as the stillgrowing field of masculinity studies illuminates. ${ }^{202}$ Feminists and future courts will be responsible for repositioning the male body as worthy of discussion and legal protection, just as the long-fought battles for female equality claim that the female body deserves such attention and respect.

Critical thinkers cannot simply accept the purported "best interests of the child"-namely, to be supported financially by both a male and a female-as an adequate response in all situations. There is, at the most basic level, a problem with the court assuming that it can determine a child's "best interests" while excluding lesbian and gay families, deliberately single-parent families, or other nontraditional family forms. ${ }^{203}$ Further investigation into the underlying policy of the "best interests of the child" rhetoric reveals that it is a part of the state's continual insistence on a private, marital, heterosexual family unit that does not require state resources. Left thinkers must demand more than this, not only because this is a system that upholds traditional stereotypes of what is an acceptable family, but also because it has proven to be an inadequate solution to providing for children and their caretakers. ${ }^{204}$ The current debate over marriage and the family provides a unique opportunity for thinking outside of the traditional framework.

\section{B. Possibilities for Change}

Martha Fineman has consistently and eloquently highlighted the problems of current family policy and jurisprudence. ${ }^{205}$ Her work is helpful in analyzing many of the issues discussed in this Comment, and her suggestions for a radical policy change illustrate a willingness not only to critique, but also to bravely challenge the very basis of the problem. ${ }^{206}$ Fineman observes that the sexual connection between a man and a woman is central to the present notion of family and that this "horizontally organized intimacy" is in turn connected to an

${ }^{202}$ See PETERSEN, supra note 142, at 41-71 (discussing masculinity studies' scholarship on the male body).

${ }^{203}$ Such other nontraditional family forms may include grandparents and other nonnuclear relatives or other community forms centered around the child.

${ }^{204}$ See supra pp. 1986-92 (arguing that the traditional family model can have a negative impact on both the child and the parent).

${ }^{205}$ See generally FINEMAN, supra note 160 (including many of Fineman's thoughts and conclusions on this topic).

${ }_{206}$ See infra text accompanying notes 207-12 (describing Fineman's analysis and applying her concepts to the cases involving male victims). 
overarching patriarchy currently in place. ${ }^{207}$ This paradigm of the family posits men as dominant and marriage as sacred. ${ }^{208}$ Such a perception is certainly upheld in S.F. and Nathaniel J., as the sexual connection was the basis for the subsequent child support, and the system requiring this child support was essentially patriarchal in its refusal to view the father as a victim. Rather, the courts insisted that the father retain his rightful place in the family structure by actively contributing to the care of the child, at least in an economic sense. ${ }^{209}$ If the male victim had been relieved of his child-support obligations, the court would have been aiding in the creation of what Fineman would term a "deviant," nonsexual mother/child family. ${ }^{210}$

Fineman's critique of the sexual family and the underlying patriarchal system should be applied to men as well as women. This system is damaging to both males and females, as we have seen in the cases of male victims of sexual crimes. First, as Fineman points out, a patriarchal vision of the family is grounded in stultifying gender stereotypes. ${ }^{211}$ Single motherhood is associated not only with immorality, but with the oft-cited specter of the welfare mother. ${ }^{212}$ She is the root of many social problems, ranging from poverty to illiteracy to drugs. ${ }^{213}$ There are also male stereotypes at work in patriarchy, such as the

${ }^{207}$ Fineman, supra note 160 , at 146 ; see id. at 145 ("The dominant paradigm ... privileges the couple as foundational and fundamental.").

${ }^{208}$ See id. at 146 (describing the male-centered and socially celebrated concept of marriage).

${ }^{209}$ See S.F. v. State ex rel. T.M., 695 So. 2d 1186, 1188 (Ala. Civ. App. 1996) ("A father has both a legal and moral duty to support his minor children.").

${ }^{210}$ Fineman writes that family structures that do not fit into the traditional nuclear model are dismissed and even feared, and that the legal system works actively to uphold this traditional model. See Fineman, supra note 172, at 227 ("The current normative system defines some families as deviant.... [meanwhile] the traditional family is considered so 'special' that the state is a necessary partner [in it]."). Single mothers, she asserts, are considered to be "deviant." See id. at 101-25 (examining the concept in the contexts of poverty, divorce, and child abuse). "The impetus for this designation seems to be that the existence of unstigmatized mothers successfully mothering outside of the traditional heterosexual family calls into question some of the basic components of patriarchal ideology." Id. at 101; see also CHAMALLAS, supra note 98, at 282 (analyzing "why single motherhood, despite its prevalence, is treated as suspect, taking as its framework the triple intersection of race, sex, and class").

${ }^{211}$ See FINEMAN, supra note 160, at 146. (recognizing that "horizontally organized intimacy" is vital to patriarchal ideology).

${ }^{212}$ See CHAMALLAS, supra note 98, at 281-88 (discussing the intersection of race, patriarchy, and class in the figure of the "welfare mother").

${ }^{213}$ See id. at 114-15 (describing how political rhetoric ties single motherhood to these social problems). It is interesting to then compare the stereotype of the passive woman present in Nathaniel J. to the image of the "welfare mother," given that single mothers in the context of the latter seem to have so much societal control. 
idea-seen in both S.F. and Nathaniel J.- that men are always the sexual aggressors and never the sexual victims. These rigid ideas contribute to such problems as the "double bind" of masculinity, the expectation discussed earlier that men be both aggressive and polite. ${ }^{214}$ There is also the image of the "irresponsible reproducer," or the "deadbeat dad," commonly invoked in political rhetoric and opposed by the fathers' rights groups. ${ }^{215}$ This stereotype serves to make male victims (already in a position of perceived weakness) look even worse for not assuming their paternal duties of care. These images reinforce the importance of critiquing such cases, as they highlight some of the ways that legal work is both reflective of, and constitutive of, popular conceptions.

One of Fineman's suggestions for change in response to the problems identified is the "abolition of the legal supports for the sexual family." ${ }^{216}$ This may appear to be extreme and unrealistic, ${ }^{217}$ yet the institution of marriage is clearly undergoing serious challenge at the moment. Many long-held beliefs are undergoing a transition, and public discourse is in flux. ${ }^{218}$ The marital emphasis in the context of child support should be challenged as a part of the general questioning occurring in the legal system. For one thing, an end to the exclusive legal supports for the sexual family would pave the way for recognizing nontraditional family forms. Also, this shift in emphasis would allow courts to address the problems of male victimization, and it would create room for upholding the ideals of consent, bodily integrity, and sexual autonomy. By utilizing the strict liability standard in these cases of male victimization and not requiring a consensual sexual relationship for the sexual family, the legal system ignores the

${ }^{214}$ See supra note 148 and accompanying text (discussing how this creates confusion for men trying to form their gender and sexual identities).

${ }^{215}$ See supra notes 151-52 and accompanying text (describing how fathers' rights groups seek to portray their members as assertive of their legal rights, yet compassionate to the plight of single mothers).

${ }^{216}$ FINEMAN, supra note 160, at 228. Fineman suggests that contracts between men and women be entered into outside the context of marriage. Id. at 229. She emphasizes that she is talking only about the removal of the legal aspects of marriage and that individuals would be free to ceremoniously indicate their commitment to each other. $I d$.

${ }^{217}$ Fineman notes that there are already legal supports in place that would make the implementation of this change less radical. For example, she discusses antenuptual agreements and other contractual commonalities that would simply occur earlier in the process. $I d$.

${ }^{218}$ See supra note 18 (detailing recent debate over gay marriage that implicates society's views toward all marriages). 
violations of male bodily integrity and sexual autonomy. ${ }^{219}$ Refocusing on the parent-child relationship would bring greater consideration to the emotional or psychological connection with the child, whereas the current system privileges the purely biological connection. When considering the underlying principles of family law, a voluntary and healthy connection between a child and her caretaker should be central. The primacy of the sexual relationship between the father and the mother is also inconsistent in its application to fathers, as illustrated by paternity-rights jurisprudence. In determining a father's rights regarding his child, the legal system-and feminists—advocates the "biology plus" approach that requires the father to demonstrate some relationship beyond the genetic tie in order to qualify for parental rights. ${ }^{220}$ This model and its underlying emphasis on consent and care should similarly apply in the context of child support, at least in situations of male victims of sexual assault or statutory rape.

The second suggestion that Fineman offers is the "construction of protections for the nurturing unit of caretaker and dependant

${ }^{219}$ The efficiency of the strict liability rule cannot trump the importance of the individual's dignity. The Supreme Court, in another context, has recognized as much. See Stanley v. Illinois, 405 U.S. 645, 656-57 (1972) ("Procedure by presumption is always cheaper and easier than individualized determination. But when ... the procedure ... explicitly disdains present realities in deference to past formalities, it needlessly risks running roughshod over the important interests of both parent and child.").

${ }^{220}$ Rosemarie Skaine compares the different paths to legal parenthood and for the unwed father there must be a "[b]iological connection and either a registration of interest or a relationship with the mother or child." ROSEMARIE SKAINE, PATERNITY AND AMERICAN LAW 33 (2003). The Supreme Court, in a series of cases, "established that unwed fathers have a right to protect their relationship with their children." Id. at 35. The right is not absolute, but will depend on the father's efforts to form a relationship with the child prior to the legal proceedings. Id.; see also Michael H. v. Gerald D., 491 U.S. 110, 124-25 (1989) ("[O]ur traditions have protected the marital family ... against the sort of claim" asserted by "the natural father to ... parental rights over a child born into a woman's existing marriage with another man.”); Lehr v. Robertson, 463 U.S. 248, 261 (1983) ("[T] he mere existence of a biological link does not merit ... constitutional protection [equivalent to that afforded an unwed father who 'demonstrates a full commitment' to parenting]. The actions of judges neither create nor sever genetic bonds.”); Caban v. Mohammed, 441 U.S. 380, 392 (1979) ("In those cases where the father never has come forward to participate in the rearing of his child, nothing in the Equal Protection Clause precludes the State from withholding from him the privilege of vetoing the adoption of that child."); Quilloin v. Walcott, 434 U.S. 246, 256 (1978) (upholding Georgia laws denying the father of an illegitimate child the right to veto an adoption by the husband of the child's mother, where father had "never shouldered any significant responsibility with respect to the daily supervision, education, protection, or care of the child"); Stanley v. Illinois, 405 U.S. 645,658 (1972) ("[A]ll ... parents are constitutionally entitled to a hearing on their fitness before their children are removed from their custody."). 
exemplified by the Mother/Child dyad." ${ }^{221}$ While creating protections for the caretaker of a child is a necessary extension of the idea of abolishing legal supports for the sexual family, I would not adopt the mother/child terminology. Fineman offers several compelling reasons for employing this gendered model, including a desire to "reclaim the term" of mother and to convey its metaphoric value for ideals of "social and emotional responsibility."222 She does not deny that men can be mothers, and she also points out that the term represents many forms of dependency beyond the actual mother and her child, including the dependency of the elderly and the disabled. ${ }^{223}$ In spite of this, I would use the gender-neutral term "caretaker." I would do so not only because a gender-neutral term is more inclusive of fathers, but also because it would actively encourage men and women to reconsider their roles in relation to reproduction, childrearing, and the family. As the above analysis has argued, the law in many ways obscures deeper thinking about the formation and portrayal of masculinity today. Feminists and others should embrace not only genderneutral terms like this one, but also the ideals underlying genderneutral terminology. These ideals-which include the conception of bodies, sex, and gender as vulnerable and ever-changing-may lead to a radical reconceptualization of the male role in reproduction and child-rearing and the revitalization of a critique of typical gender definitions under the law.

\section{CONCLUSION}

In the end, S.F. and Nathaniel J. are not merely obscure parties in some fairly odd cases. A closer look at these cases reveals that there is a multi-layered and wide-ranging analysis to be done. First, these decisions illustrate the extreme consequences of the strict liability standard for child support, and as such, they are useful border cases that may serve as starting points for a critique of less-startling fact patterns. This critique focuses on the language of the opinions, which is grounded in stereotypical views of both men and women. Feminist values, including bodily integrity and fluid conceptions of gender, are at stake. The critique also problematizes the best interests of the child standard, finding that it obscures an underlying conservative vision of sexuality and the family.

\footnotetext{
${ }^{221}$ Fineman, supra note 172, at 228.

${ }^{222} I d$. at 234.

${ }^{223}$ See id. at 234-35 ("First, I believe that men can and should be [m] others.... Second, the $[c]$ hild ... stands for all forms of inevitable dependency ....").
} 
Through this process, real problems emerge from these decisions. The cases implicate the unequal status of women, the lack of political coalitions on the Left, societal failures regarding male victims of sexual crimes, and a traditional approach to the welfare state. Martha Fineman's scholarship is a good model to use in approaching these issues, and her critique can then be expanded to include more nuanced notions of masculinity. Her work is also a source of inspiration for its willingness to advocate radical change to the legal system currently in place. The real value of such critique, however, lies not in the solutions it may find or create, but rather in the process of critiquing itself. The method used here looks beyond traditional legal concepts such as equality to engage in theoretical discourse analysis and to question traditional feminist viewpoints. The ultimate goal is to challenge our own notions and expectations and to find new approaches and tools to use in fighting for change. Given the current legal and political climate, this is the perfect moment to use such a critique and to question it further still. 